\title{
PRINCIIPIOS GERAIS E PRINCÍPIOS CONTRATUAIS: CÓDIGO CIVIL X CÓDIGO DE DEFESA DO CONSUMIDOR
}

\section{GENERAL PRINCIPLES AND CONTRACTUAL PRINCIPLES: CIVIL CODE X CONSUMER PROTECTION CODE}

\author{
Aline Martinez Pieroni \\ Mestra em Ciências pelo Departamento de Direito Civil da Faculdade de Direito da \\ Universidade de São Paulo - FDUSP. Conciliadora e Mediadora. Advogada.
}

\begin{abstract}
Resumo: 0 artigo proposto partirá da distinção entre as relações paritárias e as consumeristas, seguido pelo exame dos princípios gerais e contratuais do Código Civil de 2002 e do Código de Defesa do Consumidor, passando para a análise da modulação dos efeitos de sua incidência até chegar à reflexão sobre a possibilidade da coexistência das duas normas, mediante a apreciação de critérios hábeis a autorizar e legitimar a concorrência normativa. 0 método adotado é de revisão da doutrina e jurisprudência sobre os princípios gerais e princípios contratuais tanto na esfera do direito civil, quanto no âmbito do direito do consumidor. Ao final, três julgados brasileiros foram analisados a fim de identificar a aplicação prática pelo Judiciário do arcabouço principiológico existente em ambos os regimes.
\end{abstract}

Palavras-chave: Direito civil. Direito do consumidor. Princípios. Modulação dos efeitos. Concorrência normativa. Critérios.

Abstract: The proposed article will start from the distinction between parity and consumer relations, followed by an examination of the general and contractual principles of the Civil Code of 2002 and the Consumer Protection Code, going on to analyze the modulation of the effects of its incidence until reaching the reflection on the possibility of the coexistence of the two norms, through the assessment of criteria capable of authorizing and legitimizing normative competition. The adopted method is to revise the doctrine and jurisprudence on the general principles and contractual principles both in the sphere of civil law and in the scope of consumer law. In the end, three Brazilian judges were analyzed in order to identify the practical application by the Judiciary of the principiological framework existing in both regimes.

Keywords: Civil rights. Consumer rights. Principles. Effect modulation. Normative competition. Criteria.

Sumário: 1 Relações paritárias versus relações consumeristas - 2 Princípios gerais do Código Civil de 2002 versus princípios gerais do Código de Defesa do Consumidor - $\mathbf{3}$ Princípios contratuais: Código Civil de 2002 e Código de Defesa do Consumidor - 4 Modulação dos efeitos da incidência dos princípios à hipótese concreta - $\mathbf{5}$ Coexistência das normas: critérios para a concorrência normativa 6 Aplicação prática da modulação dos efeitos da incidência dos princípios - $\mathbf{7}$ Conclusão 


\section{Relações paritárias versus relações consumeristas}

A distinção entre relações paritárias e relações consumeristas, por si só, não define o regime jurídico ao qual se submeterá a hipótese concreta.

Apesar de o Código Civil de 2002 e o Código de Defesa do Consumidor possuírem objetivos próprios, há casos em que será possível aplicar a lei consumerista às relações paritárias e a lei civil às relações desiguais, consumeristas.

o Código Civil trata, igualmente, de normas de preservação do equilíbrio e da lealdade nas relações, como é o caso dos contratos de adesão (arts. 423 e 424 do CC e art. 54 do CDC), da lesão ou alteração das circunstâncias (art. 157 do CC e art. 6ㅇ, $\vee$ do $C D C$ ) e da responsabilidade civil (arts. 927, parágrafo único, e 931 do CC e arts. 12 e 14 do CDC).

Fábio Siebeneichler de Andrade chama à atenção para o fato de que seria um equívoco considerar que o Código de Defesa do Consumidor cuidaria da parte fraca, enquanto o Código Civil repousaria sobre o princípio da igualdade das partes, uma vez que não distingue a noção de igualdade formal e material, sendo que o Código Civil traz instrumentário também para os casos de desigualdade material entre as partes. ${ }^{1}$

Fato é que o Código Civil de 2002 é o eixo central das relações privadas, enquanto que o Código de Defesa do Consumidor é lei especial, cujo conteúdo se revela em regrar contratos consumeristas, estabelecer princípios regentes do mercado de consumo e as práticas do fornecedor e da exposição. ${ }^{2}$

Diante da vulnerabilidade presumida do consumidor que afeta a igualdade entre as partes na relação negocial, o CDC foi elaborado a partir de mandamento constitucional a fim de atribuir proteção mais forte ao vulnerável.

A ideia da distinção entre essas relações importa em auxiliar o intérprete a bem definir e delinear a situação fática a reclamar solução jurídica, de modo a proporcionar o melhor e adequado resultado que o sistema jurídico, compreendido como um todo, tem a oferecer, sem implicar, necessariamente, a definição do regime jurídico ao qual estará sujeita.

ANDRADE, Fábio Siebeneichler de. 0 modelo do Código Civil de 2002 sob a perspectiva das funções atuais da codificação. In: AZEVEDO, Antônio Junqueira de; TÔRRES, Heleno Taveira; CARBONE, Paolo (Coord.). Princípios do novo Código Civil brasileiro e outros temas: homenagem a Tullio Ascarelli. 2. ed. São Paulo: Quartier Latin, 2010. p. 186-189.

2 GODOY, Claudio Luiz Bueno de. Código Civil e Código de Defesa do Consumidor: convergência de princípios e distinção de sua modulação. Um paralelo entre os deveres que criam. In: MELGARÉ, Plínio (Org.). O direito das obrigações na contemporaneidade: estudos em homenagem ao ministro Ruy Rosado de Aguiar Júnior. Porto Alegre: Livraria do Advogado, 2014. p. 111. 


\section{Princípios gerais do Código Civil de 2002 versus princípios gerais do Código de Defesa do Consumidor}

O Código de Defesa do Consumidor, elaborado a partir de mandamento constitucional de $1988,{ }^{3}$ foi moldado à luz dos valores constitucionais.

o Código Civil de 2002 atendeu aos imperativos axiológicos constitucionais ao não descurar da tutela da pessoa humana e sofreu influência da chamada repersonalização do direito civil.

Importa, então, identificar certa convergência principiológica "que se estabelece sobre o imperativo de harmonia nas relações privadas e na ocupação básica de tutela do ser humano". 4

O Código de Defesa do Consumidor tem como princípio geral a tutela do contratante débil, sendo a fonte de deveres anexos, sobretudo o dever de informar, e traz como critério para a revisão dos contratos a onerosidade excessiva superveniente. $^{5}$

Em síntese, a doutrina aponta como princípios gerais do CDC o princípio da vulnerabilidade (corolário da igualdade material, art. 5o, XXXII da CF/88 e art. 48 do ADCT), da hipossuficiência, do acesso à Justiça por associações representativas e da facilitação da defesa (próprios do CDC), da defesa individual e coletiva, da aplicação subsidiária das normas comuns, da transparência, da boa-fé objetiva (CDC e CC), do equilíbrio, da proteção dos direitos patrimoniais e extrapatrimoniais do consumidor, da reparação integral (CDC e CC), da solidariedade, da intervenção do Estado, da efetividade e da harmonia das relações de consumo.

Por outro lado, ensina Cláudia Lima Marques, ${ }^{6}$ que o Código Civil de 2002 tem como princípios fundamentais o princípio da eticidade, da socialidade, refletido na função social (art. 421), na regra de interpretação em favor do aderente nos contratos de adesão (art. 423), na natureza social da posse a facilitar a usucapião para moradias (arts. 1.238, 1.239, 1.240 e 1.242), e na função social da

3 Ato das Disposições Constitucionais Transitórias - "Art. 48. o Congresso Nacional, dentro de cento e vinte dias da promulgação da Constituição, elaborará código de defesa do consumidor".

4 GODOY, Claudio Luiz Bueno de. Código Civil e Código de Defesa do Consumidor: convergência de princípios e distinção de sua modulação. Um paralelo entre os deveres que criam. In: MELGARÉ, Plínio (Org.). O direito das obrigações na contemporaneidade: estudos em homenagem ao ministro Ruy Rosado de Aguiar Júnior. Porto Alegre: Livraria do Advogado, 2014. p. 116-117.

5 MARTINS-COSTA, Judith. Os campos normativos da boa-fé objetiva: as três perspectivas do direito privado brasileiro. In: AZEVEDO, Antônio Junqueira de; TÔRRES, Heleno Taveira; CARBONE, Paolo (Coord.). Princípios do novo Código Civil brasileiro e outros temas: homenagem a Tullio Ascarelli. 2. ed. São Paulo: Quartier Latin, 2010. p. 399-404.

6 MARQUES, Cláudia Lima. Superação das antinomias pelo diálogo das fontes: o modelo brasileiro de coexistência entre o Código de Defesa do Consumidor e o Código Civil de 2002. In: AZEVEDO, Antônio Junqueira de; TÔRRES, Heleno Taveira; CARBONE, Paolo (Coord.). Princípios do novo Código Civil brasileiro e outros temas: homenagem a Tullio Ascarelli. 2. ed. São Paulo: Quartier Latin, 2010. p. 146-147. 
propriedade (art. 1.228), que prestigia a prevalência dos valores coletivos sobre os individuais, sem perda do valor fundamental da pessoa humana, e da operabilidade que visa facilitar a aplicação de seu texto legal.

Para Claudio Luiz Bueno de Godoy, ${ }^{7}$ há convergência de princípios básicos de ambas as leis, notadamente os princípios cardeais de elaboração do Código Civil atual, na medida em que a operabilidade refere-se à elaboração de uma lei pragmática, a socialidade ocupa-se com o atendimento, no que se refere aos direitos subjetivos, ao mesmo tempo, de um interesse individual e de um interesse social, e a eticidade preocupa-se com o "padrão ético-moral diferenciado nas relações jurídicas", abrangendo a boa-fé objetiva e o equilíbrio das relações.

Acrescenta, ainda, que a vulnerabilidade é absoluta no CDC, eis que o consumidor requer uma tutela diferenciada, enquanto que no CC precisa ser demonstrada. Trata-se de fator de interpretação, ponto de aproximação possivel entre as duas leis, uma vez que o CC prevê, igualmente, a hipótese de desigualdade da relação ao prever mecanismos de correção, como é o caso do contrato de adesão, da abusividade da cláusula penal, da lesão, da imprevisão e dos princípios no âmbito dos contratos. ${ }^{8}$

Quanto ao princípio da boa-fé objetiva (art. 4ํ, III do CDC), este deve pautar todas as relações de consumo e decorre da escolha valorativa constitucional de solidarismo. Exige transparência na base das regras sobre a formação dos contratos (art. 30 e seguintes do $\mathrm{CDC}$ ) ou sobre a publicidade do produto ou serviço (art. 36 e seguintes do CDC), como também assegura os deveres de segurança e confiança. ${ }^{9}$

Esse mesmo princípio está presente no Código Civil de 2002 como função interpretativa (art. 113), função limitativa do exercício de direitos (art. 187) e função supletiva (art. 422).

GODOY, Claudio Luiz Bueno de. Código Civil e Código de Defesa do Consumidor: convergência de princípios e distinção de sua modulação. Um paralelo entre os deveres que criam. In: MELGARÉ, Plínio (Org.). O direito das obrigações na contemporaneidade: estudos em homenagem ao ministro Ruy Rosado de Aguiar Júnior. Porto Alegre: Livraria do Advogado, 2014. p. 119-120.

8 GODOY, Claudio Luiz Bueno de. Código Civil e Código de Defesa do Consumidor: convergência de princípios e distinção de sua modulação. Um paralelo entre os deveres que criam. In: MELGARÉ, Plínio (Org.). O direito das obrigações na contemporaneidade: estudos em homenagem ao ministro Ruy Rosado de Aguiar Júnior. Porto Alegre: Livraria do Advogado, 2014. p. 117.

9 GODOY, Claudio Luiz Bueno de. Código Civil e Código de Defesa do Consumidor: convergência de princípios e distinção de sua modulação. Um paralelo entre os deveres que criam. In: MELGARÉ, Plínio (Org.). O direito das obrigações na contemporaneidade: estudos em homenagem ao ministro Ruy Rosado de Aguiar Júnior. Porto Alegre: Livraria do Advogado, 2014. p. 118. 


\section{Princípios contratuais: Código Civil de 2002 e Código de Defesa do Consumidor}

Elucida Antônio Junqueira de Azevedo, ${ }^{10} \mathrm{em}$ seu parecer sobre direito de exclusividade nas relações contratuais de fornecimento, que os princípios do direito contratual advindos do século passado gravitam em torno da autonomia da vontade, sendo eles o princípio da liberdade contratual lato sensu ("as partes podem convencionar o que querem, e como querem, dentro dos limites da lei"), o princípio da obrigatoriedade dos efeitos contratuais ("o contrato faz lei entre as partes") e o princípio da relatividade dos efeitos contratuais ("o contrato somente vincula as partes, não beneficiando nem prejudicando terceiros").

Somados a tais princípios, de acordo com o mesmo jurista, ${ }^{11}$ estão os chamados novos princípios: a boa-fé objetiva (art. 422 do CC), o equilíbrio econômico do contrato e a função social do contrato (art. 421 do CC).

A boa-fé objetiva consiste na criação de deveres entre as partes, como o dever de informar, o dever de sigilo, o dever de lealdade e o dever de proteção, presente desde a fase pré-contratual até a pós-contratual. ${ }^{12}$

$\mathrm{Na}$ fase contratual esses deveres decorrentes da boa-fé objetiva existem paralelamente ao vínculo contratual, sendo denominados deveres anexos.

Os deveres de transparência e confiança ganham a ideia de regime mais forte para as relações consumeristas, porém apresentam distinções no regime comum e no regime consumerista, como é o caso, por exemplo, da oferta. No CDC a fase de tratativas é a própria oferta, enquanto que no CC as negociações preliminares representam um convite a ofertar. ${ }^{13}$

O dever de informar encerra manifestação básica da boa-fé objetiva em sua função supletiva. No CDC aparece como dever principal (arts. 31 e 46), sendo distinta a extensão de sua exigência, consistente no nível de detalhamento da informação, em relação ao regime comum (art. 422 do CC). ${ }^{14}$

Quanto ao dever de segurança, é possível fazer um paralelo entre a responsabilidade civil nos dois sistemas. O CDC estabelece como direito básico do consumidor

AZEVEDO, Antônio Junqueira de. Estudos e pareceres de direito privado. São Paulo: Saraiva, 2004. p. 140 11 AZEVEDO, Antônio Junqueira de. Estudos e pareceres de direito privado. São Paulo: Saraiva, 2004. p. 140.

12 AZEVEDO, Antônio Junqueira de. Estudos e pareceres de direito privado. São Paulo: Saraiva, 2004. p. 141.

13 GODOY, Claudio Luiz Bueno de. Código Civil e Código de Defesa do Consumidor: convergência de princípios e distinção de sua modulação. Um paralelo entre os deveres que criam. In: MELGARÉ, Plínio (Org.). O direito das obrigações na contemporaneidade: estudos em homenagem ao ministro Ruy Rosado de Aguiar Júnior. Porto Alegre: Livraria do Advogado, 2014. p. 122-127.

14 GODOY, Claudio Luiz Bueno de. Código Civil e Código de Defesa do Consumidor: convergência de princípios e distinção de sua modulação. Um paralelo entre os deveres que criam. In: MELGARÉ, Plínio (Org.). O direito das obrigações na contemporaneidade: estudos em homenagem ao ministro Ruy Rosado de Aguiar Júnior. Porto Alegre: Livraria do Advogado, 2014. p. 127-129. 
o direito à prevenção e reparação integral, o que evidencia modelo de responsabilização mais rigoroso, objetivo, no qual o nexo de imputação é o defeito de segurança. No CC há cláusula geral de responsabilidade objetiva pelo risco da atividade ( $2^{\mathrm{a}}$ parte do parágrafo único do art. 927) e pelo fato do produto (art. 931 do CC e arts. 12 e 14 do $\mathrm{CDC}$ ). São títulos de imputação diversos, alternativos, em favor da ampla reparação do consumidor, o defeito do $\mathrm{CDC}$ e o risco especial do $\mathrm{CC}$, que pode ser aplicado à relação de consumo tão somente com relação aos serviços por meio da cláusula de abertura presente no art. $7^{\circ}$ do Código de Defesa do Consumidor. ${ }^{15}$

Antes do advento do Código Civil de 2002, a boa-fé objetiva tinha guarida nos arts. 4, inc. III, e 51, inc. IV ${ }^{16}$ do Código de Defesa do Consumidor.

Afirma Judith Martins-Costa ${ }^{17}$ que, tradicionalmente, a boa-fé objetiva possui três funções: a de cânone hermenêutico e integrativo do contrato, a de fonte de criação de deveres jurídicos e a de limitar o exercício de direitos subjetivos.

No entanto, o Código de Defesa do Consumidor atribui-lhe a função de corretora do desequilíbrio contratual, de modo que no sistema de proteção do consumidor a boa-fé é tida como mandamento de otimização do equilíbrio contratual, superpondo-se ao princípio do equilíbrio. ${ }^{18}$

Para a autora, há uma supervalorização da boa-fé no Código de Defesa do Consumidor em razão da implícita coligação entre a boa-fé e o pressuposto fático e normativo da vulnerabilidade do consumidor que reclama o equilíbrio contratual e a interpretação pró-consumidor, haja vista que a razão de ser da legislação consumerista é a efetiva e real assimetria de poderes sociais existentes entre consumidores e fornecedores no mercado de consumo. ${ }^{19}$

Há de se ter em mente, ainda, que os deveres de lealdade e a correção de condutas impõem-se a ambas as partes existentes na relação de consumo, ou seja, tanto ao consumidor quanto ao fornecedor. ${ }^{20}$

15 GODOY, Claudio Luiz Bueno de. Código Civil e Código de Defesa do Consumidor: convergência de princípios e distinção de sua modulação. Um paralelo entre os deveres que criam. In: MELGARÉ, Plínio (Org.). O direito das obrigações na contemporaneidade: estudos em homenagem ao ministro Ruy Rosado de Aguiar Júnior. Porto Alegre: Livraria do Advogado, 2014. p. 129-134.

16 “Art. 51. São nulas de pleno direito, entre outras, as cláusulas contratuais relativas ao fornecimento de produtos e serviços que: [...] IV - estabeleçam obrigações consideradas iníquas, abusivas, que coloquem o consumidor em desvantagem exagerada, ou sejam incompatíveis com a boa-fé ou a eqüidade; [...]".

17 MARTINS-COSTA, Judith. A boa-fé no direito privado: sistema e tópica no processo obrigacional. São Paulo: Revista dos Tribunais, 1999. p. 427-428.

18 MARTINS-COSTA, Judith. Os campos normativos da boa-fé objetiva: as três perspectivas do direito privado brasileiro. In: AZEVEDO, Antônio Junqueira de; TÔRRES, Heleno Taveira; CARBONE, Paolo (Coord.). Princípios do novo Código Civil brasileiro e outros temas: homenagem a Tullio Ascarelli. 2. ed. São Paulo: Quartier Latin, 2010. p. 399-404.

19 MARTINS-COSTA, Judith. Os campos normativos da boa-fé objetiva: as três perspectivas do direito privado brasileiro. In: AZEVEDO, Antônio Junqueira de; TÔRRES, Heleno Taveira; CARBONE, Paolo (Coord.). Princípios do novo Código Civil brasileiro e outros temas: homenagem a Tullio Ascarelli. 2. ed. São Paulo: Quartier Latin, 2010. p. 399-404.

20 Exemplo de utilização do princípio da boa-fé em favor do fornecedor: "CONSUMIDOR. PROPAGANDA ENGANOSA. INOCORRÊNCIA. ANÚNCIO DE PRODUTO COM PREÇO MUITO INFERIOR AO PREÇO MÉDIO 


\section{Na lição de Ruy Rosado de Aguiar Júnior:21}

A boa-fé é limitadora do direito subjetivo, augustia o âmbito da liberdade contratual, flexibiliza a estrutura material do contrato e gera certa insegurança quanto ao seu conteúdo, mas a sua finalidade principal é de manutenção e conservação do vínculo, aperfeiçoado pelos princípios da confiança, da lealdade, da honestidade e da verdade.

O princípio do equilíbrio econômico do contrato leva a admitir o instituto da lesão e da onerosidade excessiva. ${ }^{22}$

A função social do contrato visa impedir aqueles que prejudiquem a coletividade, como é o caso dos contratos contra o consumidor, por exemplo, bem como os que prejudiquem ilicitamente pessoas determinadas. O valor social da livre iniciativa, ${ }^{23}$ fixado como um dos fundamentos da República, reflete a determinação desse princípio pela Constituição Federal de $1988{ }^{24}$

DE MERCADO. EVIDENTE ERRO ESCUSÁVEL. OFERTA NÃO VINCULANTE. DANOS MORAIS INEXISTENTES. PREVALÊNCIA DO PRINCÍPIO DA BOA-FÉ. 1. Qualquer cidadão possui a capacidade de presumir que um produto como aquele adquirido pelo autor custa muito mais do que o anunciado na oferta, o que evidencia de forma ainda mais contundente a existência de erro, e não de má-fé, sendo que a flagrante desproporcionalidade entre o valor anunciado e o valor real do bem inviabiliza a pretensão inicial, interpretação que mais se adequa ao princípio da boa-fé, que rege as relações civis, comerciais e consumeristas em via de mão dupla, aplicando-se igualmente aos fornecedores e aos consumidores, sendo que o acolhimento da pretensão do autor importaria, ademais, em inadmissível enriquecimento indevido, situação inadmitida pelo ordenamento jurídico. PROCESSO CIVIL. SUCUMBÊNCIA. FORNECEDOR QUE, CANCELANDO A TRANSAÇÃO UNILATERALMENTE, NÃO PROCEDE À IMEDIATA RESTITUIÇÃO DOS VALORES PAGOS. SENTENÇA DE PROCEDÊNCIA QUANTO À RESTITUIÇÃO. REPARTIÇÃO IGUALITÁRIA DO ÔNUS SUCUMBENCIAL. INTELIGÊNCIA DO ART. 21 DO CPC/73. 2. A sentença foi de parcial procedência, e, não tendo a apelada efetuado a imediata devolução dos valores pagos pelo autor, após o cancelamento unilateral, imperioso reconhecer que, ao menos em parte, deu causa à propositura da ação, motivo pelo qual ficam os ônus de sucumbência repartidos igualmente entre as partes, nos termos do art. 21 do CPC/73, aplicável ao caso em tela. 3. Recurso parcialmente provido" (Tribunal de Justiça de São Paulo, 35ª Câmara de Direito Privado. Apelação no 1038667-13.2015.8.26.0002. Rel. Des. Artur Marques.).

21 AGUIAR JÚNIOR, Ruy Rosado de. A boa-fé na relação de consumo. Revista de Direito do Consumidor $R D C$, v. 14, n. 20, abr./jun. 1995. p. 387.

22 AZEVEDO, Antônio Junqueira de. Estudos e pareceres de direito privado. São Paulo: Saraiva, 2004. p. 141.

23 “Art. 1으 A República Federativa do Brasil, formada pela união indissolúvel dos Estados e Municípios e do Distrito Federal, constitui-se em Estado Democrático de Direito e tem como fundamentos: [...] IV - os valores sociais do trabalho e da livre iniciativa. [...] Art. 170. A ordem econômica, fundada na valorização do trabalho humano e na livre iniciativa, tem por fim assegurar a todos existência digna, conforme os ditames da justiça social, observados os seguintes princípios: I - soberania nacional; II - propriedade privada; III - função social da propriedade; IV - livre concorrência; V - defesa do consumidor; VI - defesa do meio ambiente, inclusive mediante tratamento diferenciado conforme o impacto ambiental dos produtos e serviços e de seus processos de elaboração e prestação; VII - redução das desigualdades regionais e sociais; VIII - busca do pleno emprego; IX - tratamento favorecido para as empresas de pequeno porte constituídas sob as leis brasileiras e que tenham sua sede e administração no País. Parágrafo único. É assegurado a todos o livre exercício de qualquer atividade econômica, independentemente de autorização de órgãos públicos, salvo nos casos previstos em lei".

24 AZEVEDO, Antônio Junqueira de. Estudos e pareceres de direito privado. São Paulo: Saraiva, 2004. p. 141. 
Desse princípio decorre que qualquer contrato tem importância para toda a sociedade e que terceiros não podem se comportar como se o contrato não existisse, tornando o contrato oponivel a terceiros.

Esse dever de respeito ao contrato por terceiros já existia por força do art. 159 do Código Civil de $1916,{ }^{25}$ cláusula geral do sistema, correspondente ao art. 186 combinado com o art. 927, do Código Civil de 2002. ${ }^{26}$

A Constituição Federal de 1988 tornou a defesa do consumidor um princípio geral da ordem econômica (art. 170, inc. V), além de ter determinado, no art. 48 do ato das disposições constitucionais transitórias, a elaboração do Código de Defesa do Consumidor, no prazo de 180 dias a partir de sua promulgação, a fim de atender aos reclamos de proteção da contratação em massa. ${ }^{27}$

Antes do advento do Código de Defesa do Consumidor, o consumidor era pessoa desamparada diante da economia de massa e o poder econômico, público e privado.

Os princípios de direito contratual foram trazidos para o Código Consumerista, quais sejam, o princípio geral da boa-fé (art. 51, inc. IV), o princípio da obrigatoriedade da proposta (art. 51, inc. VIII) e o princípio da intangibilidade das convenções (art. 51, incs. X, XI e XIII). ${ }^{28}$

Com a proibição da vantagem exagerada do fornecedor, o Código de Defesa do Consumidor reanima os princípios tradicionais da lesão nos contratos e da excessiva onerosidade, (art. 51, §1ํㅡ) presentes igualmente no Código Civil de 2002.

O rol exemplificativo das cláusulas abusivas está previsto no mesmo art. 51 , do Código em comento, cabendo à Secretaria de Direito Econômico editar, anualmente, lista complementar de cláusulas consideradas abusivas, nos termos do art. 56, do Decreto ํㅡ 2.181/97, que dispõe sobre a organização do Sistema Nacional de Defesa do Consumidor - SNDC. ${ }^{29}$ As cláusulas abusivas violam o princípio da boa-fé objetiva.

25 “Art. 159. Aquele que, por ação ou omissão voluntária, negligência, ou imprudência, violar direito, ou causar prejuízo a outrem, fica obrigado a reparar o dano". A verificação da culpa e a avaliação da responsabilidade regulam-se pelo disposto neste Código, arts. 1.521 a 1.532 e 1.542 a 1.553.

26 AZEVEDO, Antônio Junqueira de. Estudos e pareceres de direito privado. São Paulo: Saraiva, 2004. p. 142.

27 VENOSA, Sílvio de Salvo. Direito civil: teoria geral das obrigações e teoria geral dos contratos. 4. ed. São Paulo: Atlas, 2004. 2. v. p. 384.

28 VENOSA, Sílvio de Salvo. Direito civil: teoria geral das obrigações e teoria geral dos contratos. 4. ed. São Paulo: Atlas, 2004. 2. v. p. 385

29 “Art. 56. Na forma do art. 51 da Lei no 8.078, de 1990, e com o objetivo de orientar o Sistema Nacional de Defesa do Consumidor, a Secretaria Nacional do Consumidor divulgará, anualmente, elenco complementar de cláusulas contratuais consideradas abusivas, notadamente para o fim de aplicação do disposto no inciso IV do caput do art. 22. §1ํNa elaboração do elenco referido no caput e posteriores inclusões, a consideração sobre a abusividade de cláusulas contratuais se dará de forma genérica e abstrata. §2ํㅜ 0 elenco de cláusulas consideradas abusivas tem natureza meramente exemplificativa, não impedindo que outras, também, possam vir a ser assim consideradas pelos órgãos da Administração Pública incumbidos da defesa dos interesses e direitos protegidos pelo Código de Defesa do Consumidor e legislação correlata. §3ำ A apreciação sobre a abusividade de cláusulas contratuais, para fins de sua inclusão no elenco 
Para Sílvio de Salvo Venosa, cabe ao juiz definir a abusividade de cláusula, independentemente de descrição legal específica, de modo que o intérprete deve aplicar a lei ao caso concreto a partir dos novos princípios, positivados pela lei de consumo, devendo ser aplicados sempre que oportunos e convenientes em todo contrato e não unicamente nas relações de consumo, revelando-se "um caminho mais seguro para o julgador, em todo exame do universo contratual e não exclusivamente no campo do consumidor". ${ }^{30}$

Acrescenta, ainda, que o juiz deve ter sempre em mente, na aferição do caso concreto, os princípios, as regras gerais e as cláusulas abertas de todos os contratos.

\section{Modulação dos efeitos da incidência dos princípios à hipótese concreta}

o Código Civil de 2002 e o Código de Defesa do Consumidor escoram-se em princípios convergentes, com espaços de recíproca influência e interpretação, no entanto divergem quanto ao seu âmbito de incidência e aos espaços de recíproca influência, ou seja, "a interface que entre eles se abre". ${ }^{31}$

Ensina Claudio Luiz Bueno de Godoy ${ }^{32}$ que a distinção entre os princípios está "na modulação de sua incidência, na intensidade com que ordenam e interferem nos vínculos obrigacionais", ou seja, na intensidade ou calibração das exigências valorativas da hipótese concreta. Apesar de apresentarem realidade ontológica comum, estão presentes em ambos os códigos que possuem objetivos diferentes. "Não se pode conceber a mesma extensão para as relações desiguais e para aquelas forjadas entre iguais", de modo que essa regra deve nortear a atividade judicial de correção. ${ }^{33}$

a que se refere o caput deste artigo, se dará de ofício ou por provocação dos legitimados referidos no art. 82 da Lei no 8.078, de 1990".

30 VENOSA, Sílvio de Salvo. Direito civil: teoria geral das obrigações e teoria geral dos contratos. 4. ed. São Paulo: Atlas, 2004. 2. v. p. 385.

31 GODOY, Claudio Luiz Bueno de. Código Civil e Código de Defesa do Consumidor: convergência de princípios e distinção de sua modulação. Um paralelo entre os deveres que criam. In: MELGARÉ, Plínio (Org.). O direito das obrigações na contemporaneidade: estudos em homenagem ao ministro Ruy Rosado de Aguiar Júnior. Porto Alegre: Livraria do Advogado, 2014. p. 109.

32 GODOY, Claudio Luiz Bueno de. Código Civil e Código de Defesa do Consumidor: convergência de princípios e distinção de sua modulação. Um paralelo entre os deveres que criam. In: MELGARÉ, Plínio (Org.). O direito das obrigações na contemporaneidade: estudos em homenagem ao ministro Ruy Rosado de Aguiar Júnior. Porto Alegre: Livraria do Advogado, 2014. p. 109-110.

33 GODOY, Claudio Luiz Bueno de. Código Civil e Código de Defesa do Consumidor: convergência de princípios e distinção de sua modulação. Um paralelo entre os deveres que criam. In: MELGARÉ, Plínio (Org.). O direito das obrigações na contemporaneidade: estudos em homenagem ao ministro Ruy Rosado de Aguiar Júnior. Porto Alegre: Livraria do Advogado, 2014. p. 120. 
Portanto, os princípios comuns a ambos os regimes, em razão da vocação normativa que cada um ostenta, sofrem a calibração das exigências valorativas, cujo resultado é a variação de intensidade de sua aplicação e nas regras que criam à hipótese fática.

\section{Coexistência das normas: critérios para a concorrência normativa}

O ponto de toque entre o direito civil e o direito do consumidor é a seara contratual, ou melhor dizendo, as relações negociais.

O fato que traz em si uma relação negocial deve ser apreciado pelo intérprete da lei a partir da identificação da relação existente entre as partes a fim de que possa definir o regime jurídico ao qual se sujeita.

Longe de ser tarefa simples, no momento de examinar qual regime jurídico incidirá em determinada relação negocial, cabe ao operador do direito atentar-se ao tipo de relação existente, aos princípios gerais do direito civil e do direito do consumidor, aos princípios contratuais e à modulação dos efeitos de sua incidência e dos deveres que criam.

Nesse ponto, Paulo Lôbo ${ }^{34}$ assevera:

[...] a utilização de princípios e cláusulas gerais constituem ferramentas hermenêuticas indispensáveis e imprescindíveis para a sociedade em mudanças, para a realização das finalidades da justiça social e para o trato adequado do fenômeno avassalador da manifestação contratual e da parte contratante vulnerável.

Contudo, a partir dessa reflexão, será possível se deparar com casos em que a situação fática exija solução própria de um dos sistemas ou de ambos, concomitantemente, a fim de assegurar uma solução mais adequada e em consonância com a lógica do sistema jurídico nacional.

É nesse ponto, na possibilidade de coexistência das normas, que a doutrina se divide e que demanda maior estudo sobre ambas as normas, atrelado aos princípios que as norteiam, para se chegar à conclusão sobre como se dará a aplicação das normas e sob qual ou quais critérios e fundamentos.

34 LÔBO, Paulo Luiz Netto. Condições gerais dos contratos e o novo Código Civil brasileiro. In: AZEVEDO, Antônio Junqueira de; TÔRRES, Heleno Taveira; CARBONE, Paolo (Coord.). Princípios do novo Código Civil brasileiro e outros temas: homenagem a Tullio Ascarelli. 2. ed. São Paulo: Quartier Latin, 2010. p. 550. 
Defende Sérgio Cavalieri a coexistência de múltiplas normas, para quem o critério de aplicação é encontrar a norma que melhor se ajusta ao caso concreto com base nos princípios que regem a matéria, invocando a doutrina moderna do "diálogo das fontes". ${ }^{35}$

Para Sílvio de Salvo Venosa, a lei consumerista não conflita com os postulados básicos do direito contratual e do direito privado, e define a vulnerabilidade como critério para a aplicação do Código de Defesa do Consumidor ao ato ou ao negócio, bastando que se identifique o "consumidor na relação negocial e que nessa relação esteja presente o caráter de sua vulnerabilidade", ou seja, a relação de consumo. ${ }^{36}$

0 autor conclui dizendo que a lei consumerista reflete a inutilidade da divisão clássica do direito em público e privado, por se interpenetrarem os seus ramos, sendo o Código de Defesa do Consumidor um direito social, de maneira que a premissa básica para o exame da teoria geral dos contratos e dos contratos em espécie é "verificar o alcance do pacto dentro do Código de Defesa do Consumidor". ${ }^{37}$

Cláudia Lima Marques ${ }^{38}$ faz interessante construção doutrinária sobre os conflitos entre normas do Código Civil, de leis especiais e de leis anteriores com o Código de Defesa do Consumidor a partir do seguinte questionamento: em qual diploma legal será encontrado o regime jurídico básico e o regime jurídico especial para o contrato que se apresenta?

A autora remete à Lei de Introdução das Normas do Direito Brasileiro, DecretoLei no 4.657, de 4.9.1942, para tratar dos conflitos de leis no tempo.

Para a jurista, o conflito em apreço seria solucionado pelo $\S^{2} \stackrel{\circ}{ }$ do art. $2^{\circ}$, da referida lei, ao determinar que a lei nova especial não revogará e tampouco modificará a lei geral anterior que estabeleça disposições especiais "a par das já existentes". A título de exemplo, menciona a noção de vício trazida pelos arts. 18 e 25 do Código de Defesa do Consumidor e o vício redibitório do art. 441 e seguintes do Código Civil de 2002 que, apesar de ambos disporem sobre vício, são totalmente diversos, como pode ser observado em relação aos seus prazos de decadência do direito de reclamá-los e quanto à exoneração contratual da responsabilidade, mas nem por isso a norma do Código Civil será revogada, essa só não será utilizada em caso de contrato de consumo. ${ }^{39}$

35 CAVALIERI FILHO, Sérgio. Programa de responsabilidade civil. 11. ed. rev. e ampl. São Paulo: Atlas, 2014. p. 8.

36 VENOSA, Sílvio de Salvo. Direito civil: teoria geral das obrigações e teoria geral dos contratos. 4. ed. São Paulo: Atlas, 2004. 2. v. p. 386-387.

37 VENOSA, Sílvio de Salvo. Direito civil: teoria geral das obrigações e teoria geral dos contratos. 4. ed. São Paulo: Atlas, 2004. 2. v. p. 387.

38 MARQUES, Cláudia Lima. Contratos no Código de Defesa do Consumidor: o novo regime das relações contratuais. 3. ed. rev. atual. e ampl. São Paulo: Revista dos Tribunais, 1998. p. 242.

39 MARQUES, Cláudia Lima. Contratos no Código de Defesa do Consumidor: o novo regime das relações contratuais. 3. ed. rev. atual. e ampl. São Paulo: Revista dos Tribunais, 1998. p. 243. 
A doutrinadora acrescenta:

Na prática, os efeitos se aproximam, mas a sobrevivência das regras gerais é importante porque nem todos os contratos serão regidos pela nova lei, nem todos podem ser sempre caracterizados como consumidores e nem o CDC regulou toda matéria referente à existência, à validade e à eficácia dos contratos. ${ }^{40}$

Essa interpretação é reforçada com o argumento de que mesmo os contratos regulados por leis especiais se submetem às normas gerais do Código de Defesa do Consumidor, por força do seu caráter de norma de ordem pública, como é o caso do contrato de transporte aéreo sobre o qual o espírito protetor da lei consumerista exige que suas normas sobre cláusulas abusivas sejam aplicadas para anular cláusula nele presente. ${ }^{41}$

Assim, em caso de contrato de consumo, a aplicação da legislação especial seria afastada "naquilo que incompatível com o espírito protetor" do Código de Defesa do Consumidor, sendo que o seu art. $7^{\circ}$ considera aplicável ao sistema de proteção ao consumidor outros "direitos"..$^{42}$

A autora defende que o Código de Defesa do Consumidor é lei de função social com o objetivo de uma "nova harmonia, lealdade e transparência nas relações de consumo", que requer "nova interpretação das antigas normas, quando a relação for de consumo e ambas as normas encontrarem aplicação", de modo que na impossibilidade de compatibilização entre as normas, o intérprete deverá optar por um dos sistemas para solucionar a antinomia, considerada atividade causídica e subjetiva. ${ }^{43}$

Conclui dizendo que a lei consumerista está na posição de lei especial-subjetiva e hierarquicamente superior, como lei de ordem pública e complementar ao mandamento constitucional, e que, quando utilizados os critérios clássicos para afastar a antinomia (cronológico, hierárquico e da especialização) não for possível determinar a norma aplicável, o intérprete poderá se valer da Constituição para examinar qual das normas em conflito assegura a proteção do consumidor

40 MARQUES, Cláudia Lima. Contratos no Código de Defesa do Consumidor: o novo regime das relações contratuais. 3. ed. rev. atual. e ampl. São Paulo: Revista dos Tribunais, 1998. p. 243.

41 MARQUES, Cláudia Lima. Contratos no Código de Defesa do Consumidor: o novo regime das relações contratuais. 3. ed. rev. atual. e ampl. São Paulo: Revista dos Tribunais, 1998. p. 243.

42 MARQUES, Cláudia Lima. Contratos no Código de Defesa do Consumidor: o novo regime das relações contratuais. 3. ed. rev. atual. e ampl. São Paulo: Revista dos Tribunais, 1998. p. 244.

43 MARQUES, Cláudia Lima. Contratos no Código de Defesa do Consumidor: o novo regime das relações contratuais. 3. ed. rev. atual. e ampl. São Paulo: Revista dos Tribunais, 1998. p. 245. 
e protege interesses por essa valorados, "como o direito à vida, à inviolabilidade pessoal, à propriedade, à livre iniciativa etc.". ${ }^{44}$

Na lição de Fábio Siebeneichler de Andrade, ${ }^{45}$ o Código de Defesa do Consumidor trouxe uma função de renovação do direito privado em relação ao Código Civil de 1916, eis que foi a primeira lei a ter o princípio da boa-fé, o que levou à sensível alteração principiológica no direito privado. Por outro lado, o Código Civil de 2002 não faz qualquer referência a temas tratados exclusivamente pelo Código de Defesa do Consumidor.

0 autor defende a conveniência e indispensabilidade no debate sobre a integração do direito civil e o direito do consumidor, invocando os modelos jurídicos alemão e italiano.

No direito alemão, há integração entre o direito civil e o direito do consumidor. Em 2000, os conceitos de consumidor e empresário foram incorporados à parte geral do BGB e em 2001 houve a reforma de todo o direito das obrigações com a inserção no Código Civil alemão de todas as matérias relativas à tutela do consumidor ( $\$ 305$ e seguintes do BGB) e direito de arrependimento ( $\$ \S 355$ a 359 do BGB).

No direito italiano, no Código Civil de 1942 foi inserida a matéria concernente às cláusulas abusivas.

Em outro estudo, Cláudia Lima Marques ${ }^{46}$ sustenta que novas soluções plurais visam evitar a antinomia pela correta definição dos campos de aplicação, aduzindo à noção de "coerência derivada ou restaurada" como a procura de harmonia ou coordenação entre as diversas normas do ordenamento jurídico que busca eficiência hierárquica e funcional.

A autora conclui que a solução atual da antinomia é o diálogo ${ }^{47}$ entre o Código de Defesa do Consumidor e o Código Civil de 2002, de forma sistemática e tópica, permitindo a convivência de leis com campos de aplicação diferentes, sendo que o desafio é aplicar as fontes em diálogo de maneira justa em um "sistema de Direito Privado plural, fluido, mutável e complexo". ${ }^{48}$

44 MARQUES, Cláudia Lima. Contratos no Código de Defesa do Consumidor: o novo regime das relações contratuais. 3. ed. rev. atual. e ampl. São Paulo: Revista dos Tribunais, 1998. p. 246.

45 ANDRADE, Fábio Siebeneichler de. O modelo do Código Civil de 2002 sob a perspectiva das funções atuais da codificação. In: AZEVEDO, Antônio Junqueira de; TÔRRES, Heleno Taveira; CARBONE, Paolo (Coord.). Princípios do novo Código Civil brasileiro e outros temas: homenagem a Tullio Ascarelli. 2. ed. São Paulo: Quartier Latin, 2010. p. 186-189.

46 MARQUES, Cláudia Lima. Superação das antinomias pelo diálogo das fontes: o modelo brasileiro de coexistência entre o Código de Defesa do Consumidor e o Código Civil de 2002. In: AZEVEDO, Antônio Junqueira de; TÔRRES, Heleno Taveira; CARBONE, Paolo (Coord.). Princípios do novo Código Civil brasileiro e outros temas: homenagem a Tullio Ascarelli. 2. ed. São Paulo: Quartier Latin, 2010. p. 156-157.

47 Trata-se da teoria do diálogo das fontes criada por Erik Jayme e introduzida no Brasil por Cláudia Lima Marques.

48 MARQUES, Cláudia Lima. Superação das antinomias pelo diálogo das fontes: o modelo brasileiro de coexistência entre o Código de Defesa do Consumidor e o Código Civil de 2002. In: AZEVEDO, Antônio Junqueira de; TÔRRES, Heleno Taveira; CARBONE, Paolo (Coord.). Princípios do novo Código Civil brasileiro e outros temas: homenagem a Tullio Ascarelli. 2. ed. São Paulo: Quartier Latin, 2010. p. 156-158. 
Para tanto, a doutrinadora faz a seguinte classificação em relação à teoria do diálogo das fontes: "diálogo sistemático de coerência", "diálogo sistemático de complementariedade e subsidiariedade", e "diálogo de coordenação e adaptação sistemática". ${ }^{49}$

Por meio do diálogo sistemático de coerência, uma lei serve de base conceitual para outra lei.

O diálogo sistemático de complementariedade e subsidiariedade, por sua vez, é utilizado em antinomias aparentes ou reais, em que subsidiariamente pode ser usada outra lei para regular aspectos de relação de consumo se trouxerem normas mais favoráveis ao consumidor, como é o caso do sistema geral de responsabilidade civil sem culpa e o sistema de decadência. Caberá ao legislador ${ }^{50}$ ou ao juiz ${ }^{51}$ a escolha daquela norma que vai "complementar" a ratio da outra norma.

O diálogo de coordenação e adaptação sistemática possibilita a redefinição do campo de aplicação de uma lei mediante a influência do sistema especial no geral e do geral no especial.

Cláudia Lima Marques traz, ainda, alguns exemplos do diálogo que defende entre o sistema civilista e o sistema consumerista, na modalidade de diálogo sistemático de complementariedade e subsidiariedade, como é o caso do regime de informação e oferta ao público (art. 429 do CC e arts. 30 e 35 do CDC), que tem em comum o princípio da confiança em ambos os regimes, porém apresentam campo de aplicação e finalidades distintas.

É o caso, igualmente, da oferta e da proposta (arts. 427 a 435 do CC e arts. 30 e 35 do $(D C)$ em que há maior reflexo da boa-fé e probidade nas relações negociais, tendo em comum a proteção da confiança.

49 MARQUES, Cláudia Lima. Superação das antinomias pelo diálogo das fontes: o modelo brasileiro de coexistência entre o Código de Defesa do Consumidor e o Código Civil de 2002. In: AZEVEDO, Antônio Junqueira de; TÔRRES, Heleno Taveira; CARBONE, Paolo (Coord.). Princípios do novo Código Civil brasileiro e outros temas: homenagem a Tullio Ascarelli. 2. ed. São Paulo: Quartier Latin, 2010. p. 160.

50 Algumas hipóteses de opção pelo legislador da utilização complementar e subsidiária de outra norma estão previstas nos arts. 721, 729, 732 e 777, do Código Civil de 2002: “Art. 721. Aplicam-se ao contrato de agência e distribuição, no que couber, as regras concernentes ao mandato e à comissão e as constantes de lei especial. [...] Art. 729. Os preceitos sobre corretagem constantes deste Código não excluem a aplicação de outras normas da legislação especial. [...] Art. 732. Aos contratos de transporte, em geral, são aplicáveis, quando couber, desde que não contrariem as disposições deste Código, os preceitos constantes da legislação especial e de tratados e convenções internacionais. [...] Art. 777 . 0 disposto no presente Capítulo aplica-se, no que couber, aos seguros regidos por leis próprias".

51 É o caso do favor debilis presente no art. 7을 do Código de Defesa do Consumidor: “Art. 7ํㅡ Os direitos previstos neste código não excluem outros decorrentes de tratados ou convenções internacionais de que o Brasil seja signatário, da legislação interna ordinária, de regulamentos expedidos pelas autoridades administrativas competentes, bem como dos que derivem dos princípios gerais do direito, analogia, costumes e eqüidade. Parágrafo único. Tendo mais de um autor a ofensa, todos responderão solidariamente pela reparação dos danos previstos nas normas de consumo". 
Os contrapontos básicos entre ambos os regimes são: a) o Código Civil de 2002 prestigia a teoria da vontade, enquanto que no Código de Defesa do Consumidor a figura existente é a teoria da declaração; b) no Código Civil de 2002 a responsabilidade objetiva é exceção, enquanto que no Código de Defesa do Consumidor essa é a regra; c) no Código Civil de 2002 está prevista a boa-fé objetiva, enquanto que no Código de Defesa do Consumidor há igual previsão, porém com maior intensidade; d) há o paradigma ético social de que as relações reguladas pelo Código Civil seriam paritárias, enquanto que no Código de Defesa do Consumidor prevalece a proteção do mais fraco; e) no Código Civil de 2002 a regra é a revogabilidade, ${ }^{52}$ enquanto que o Código de Defesa do Consumidor prevê a irrevogabilidade como regra; e f) no Código Civil a vinculação é menor, enquanto que no Código de Defesa do Consumidor a vinculação é maior. ${ }^{53}$

A jurista defende, portanto, em caso de antinomia, o diálogo de subsidiariedade para quem se aplica primeiro o Código de Defesa do Consumidor e somente no que couber o Código Civil, cuja aplicação de ambos os regimes deve ser ordenada, subsidiária e especial.

Na lição de Claudio Luiz Bueno de Godoy, ${ }^{54}$ o desafio é traçar critérios de convivência, ou não, entre as mais diferentes fontes do direito, diante da insuficiência dos critérios comuns de hierarquia, especialidade e cronologia.

O autor aponta os seguintes critérios trazidos pela doutrina: a) favor debilis (princípio do maior favorecimento), de modo que a doutrina se divide em favor da aplicação do art. 7º, do Código de Defesa do Consumidor, ou na aplicação do CDC sempre que houver relação de consumo, critério que traz insegurança sobre a regra aplicável; b) primazia do CDC em caso de relação de consumo e remição ao CC somente em caso de lacuna no sistema especial, preenchendo-se os requisitos da analogia e desde que não conflite com os princípios reguladores das relações de consumo (posição intermediária), o que pode implicar desfavorecimento do consumidor, uma vez que a norma deverá ser aplicada por inteiro com seus bônus

52 Art. 428, do Código Civil de 2002: “Art. 428. Deixa de ser obrigatória a proposta: I - se, feita sem prazo a pessoa presente, não foi imediatamente aceita. Considera-se também presente a pessoa que contrata por telefone ou por meio de comunicação semelhante; II - se, feita sem prazo a pessoa ausente, tiver decorrido tempo suficiente para chegar a resposta ao conhecimento do proponente; III - se, feita a pessoa ausente, não tiver sido expedida a resposta dentro do prazo dado; IV - se, antes dela, ou simultaneamente, chegar ao conhecimento da outra parte a retratação do proponente".

53 MAROUES, Cláudia Lima. Superação das antinomias pelo diálogo das fontes: o modelo brasileiro de coexistência entre o Código de Defesa do Consumidor e o Código Civil de 2002. In: AZEVEDO, Antônio Junqueira de; TÔRRES, Heleno Taveira; CARBONE, Paolo (Coord.). Princípios do novo Código Civil brasileiro e outros temas: homenagem a Tullio Ascarelli. 2. ed. São Paulo: Quartier Latin, 2010. p. 164-165.

54 GODOY, Claudio Luiz Bueno de. Código Civil e Código de Defesa do Consumidor: convergência de princípios e distinção de sua modulação. Um paralelo entre os deveres que criam. In: MELGARÉ, Plínio (Org.). $O$ direito das obrigações na contemporaneidade: estudos em homenagem ao ministro Ruy Rosado de Aguiar Júnior. Porto Alegre: Livraria do Advogado, 2014. p. 111. 
e ônus; e c) abertura do art. $7^{\circ}$ do CDC em favor do consumidor e do fornecedor a partir da aferição da particular condição das partes. ${ }^{55}$

Em seu comentário ao Código Brasileiro de Defesa do Consumidor, Nelson Nery Júnior ${ }^{56}$ defende que são regidas pelo CDC somente as relações formadas entre fornecedor e consumidor, sendo que em caso de omissão são aplicáveis à relação de consumo as disposições do $\mathrm{CC}$ e demais leis extravagantes.

Com a intenção de auxiliar o intérprete na definição sobre qual lei seria aplicável a dada situação fática, trazendo um ao outro (CDC e CC) ou misturando seus regimes, Claudio Luiz Bueno de Godoy ${ }^{57}$ traça alguns pontos a fim de nortear a atividade de coordenação e harmonização da aplicação do CC e do CDC.

0 primeiro deles é a presenvação da coerência sistemática, mediante interpretação e operacionalização dos "mecanismos sistemáticos de tal arte a se chegar a um resultado inteligente", "que prestigie as escolhas valorativas erigidas em especial em um sistema axiológico, não mais axiomático". ${ }^{58}$

0 ponto seguinte é o respeito à coerência valorativa que consiste em verificar o princípio que está em jogo. "A máxima eficácia do princípio a observar há de atrair regramento próprio para a hipótese da vida a disciplinar". ${ }^{59}$

0 próximo ponto é procurar os pontos de aproximação dos sistemas comum e consumerista para evitar determinação arbitrária do regime legal a ser aplicado.

Por último, o ponto que trata de verificar a existência de disposições de abertura para a integração do Código de Defesa do Consumidor pelo Código Civil (art. 7으, CDC), ou o inverso (art. 421 do CC, por exemplo). ${ }^{60}$

55 GODOY, Claudio Luiz Bueno de. Código Civil e Código de Defesa do Consumidor: convergência de princípios e distinção de sua modulação. Um paralelo entre os deveres que criam. In: MELGARÉ, Plínio (Org.). O direito das obrigações na contemporaneidade: estudos em homenagem ao ministro Ruy Rosado de Aguiar Júnior. Porto Alegre: Livraria do Advogado, 2014. p. 113-115.

56 NERY JÚNIOR, Nelson. Disposições finais. In: GRINOVER, Ada Pellegrini (et al.). Código Brasileiro de Defesa do Consumidor. comentado pelos autores do anteprojeto. 8. ed. Rio de Janeiro: Forense Universitária, 2005. p. 1.040.

57 GODOY, Claudio Luiz Bueno de. Código Civil e Código de Defesa do Consumidor: convergência de princípios e distinção de sua modulação. Um paralelo entre os deveres que criam. In: MELGARÉ, Plínio (Org.). O direito das obrigações na contemporaneidade: estudos em homenagem ao ministro Ruy Rosado de Aguiar Júnior. Porto Alegre: Livraria do Advogado, 2014. p. 115.

58 GODOY, Claudio Luiz Bueno de. Código Civil e Código de Defesa do Consumidor: convergência de princípios e distinção de sua modulação. Um paralelo entre os deveres que criam. In: MELGARÉ, Plínio (Org.). O direito das obrigações na contemporaneidade: estudos em homenagem ao ministro Ruy Rosado de Aguiar Júnior. Porto Alegre: Livraria do Advogado, 2014. p. 115.

59 GODOY, Claudio Luiz Bueno de. Código Civil e Código de Defesa do Consumidor: convergência de princípios e distinção de sua modulação. Um paralelo entre os deveres que criam. In: MELGARÉ, Plínio (Org.). O direito das obrigações na contemporaneidade: estudos em homenagem ao ministro Ruy Rosado de Aguiar Júnior. Porto Alegre: Livraria do Advogado, 2014. p. 115.

60 GODOY, Claudio Luiz Bueno de. Código Civil e Código de Defesa do Consumidor: convergência de princípios e distinção de sua modulação. Um paralelo entre os deveres que criam. In: MELGARÉ, Plínio (Org.). O direito das obrigações na contemporaneidade: estudos em homenagem ao ministro Ruy Rosado de Aguiar Júnior. Porto Alegre: Livraria do Advogado, 2014. p. 115-116. 
Sobre o tema, Leonardo Roscoe Bessa ${ }^{61}$ destaca que o Superior Tribunal de Justiça se preocupa com a aplicação simultânea e harmônica de diversos diplomas no julgamento de recursos relacionados à relação de consumo, porém na maioria das vezes não menciona expressamente tratar-se de diálogo das fontes a técnica utilizada para essa aplicação.

Para Gustavo Tepedino, ${ }^{62}$ o que autoriza a utilização do CDC nas relações interprivadas é "o fato de a Constituição definir valores que devem suscitar a analogia nas hipóteses de identidade de ratio", sendo que os princípios que norteiam as relações de consumo se associam cada vez mais à "preocupação constitucional com a redução das desigualdades e com o efetivo exercício da cidadania, perspectiva que não poderia deixar de compreender, segundo a vontade normativa do constituinte, as relações consideradas de direito privado".

Em suas palavras:

Acredito, entretanto, que será possível tranquilamente a aplicação do Código de Defesa do Consumidor, mesmo em situações em que não haja propriamente uma relação de consumo, desde que identifiquemos os pressupostos essenciais de hipossuficiência que justificam e dão legitimidade normativa à tutela do consumidor. Este, antes de ser consumidor, é pessoa humana, para cuja proteção se volta inteiramente o constituinte. Cuida-se de localizar, portanto, os pressupostos essenciais que, segundo o Código de Proteção do Consumidor, são necessários e suficientes para atrair uma série de princípios em defesa do sujeito de direito em situação de inferioridade. ${ }^{63}$

Entende pela possibilidade da aplicação conjunta entre o CDC e o CC, de modo complementar, André Vicente Seifert da Silva, ${ }^{64}$ a fim de buscar o equilíbrio contratual entre as partes e aplicar os dispositivos legais sem prejuízos aos consumidores, respeitando o campo de atuação de cada instituto e os princípios existentes em ambas as leis.

61 BESSA, Leonardo Roscoe. Diálogo das fontes no Direito do Consumidor: a visão do Superior Tribunal de Justiça. In: MARQUES, Cláudia Lima (Coord.). Diálogo das fontes: do conflito à coordenação de normas do direito brasileiro. São Paulo: Revista dos Tribunais, 2012. p. 187-188.

62 TEPEDINO, Gustavo. Temas de direito civil. 4. ed. rev. e atual. Rio de Janeiro: Renovar, 2008. p. 244-246.

63 TEPEDINO, Gustavo. Temas de direito civil. 4. ed. rev. e atual. Rio de Janeiro: Renovar, 2008. p. 244.

64 SILVA, André Vicente Seifert da. As convergências e as assimetrias dos contratos no Código de Defesa do Consumidor e no novo Código Civil. In: MARQUES, Cláudia Lima. Revista de Direito do Consumidor, São Paulo, ano 17, n. 65, jan./mar. 2008. p. 42 


\section{Aplicação prática da modulação dos efeitos da incidência dos princípios}

Vejamos, em três situações tópicas, como o Poder Judiciário construiu a solução jurídica ao caso posto a partir das normas previstas no Código Civil de 2002 e no Código de Defesa do Consumidor, mediante a utilização de princípios a nortear ambos os regimes.

Foi identificada uma série de situações em que a discussão levada ao Judiciário envolve a interface entre o Código Civil de 2002 e o Código de Defesa do Consumidor, em que há coincidência de princípios. Os casos mais comuns são os que tratam do contrato de transporte aéreo internacional, do contrato de promessa de compra e venda de imóvel na planta, da autonomia da vontade e vícios de consentimento, do contrato de adesão, do contrato de seguro-saúde e plano de saúde, do contrato de financiamento, do contrato bancário, do contrato de transporte de pessoas, do contrato de prestação de serviço para fornecimento de água e coleta de esgoto, e da questão sobre se os honorários advocatícios contratuais integrariam o valor devido a título de perdas e danos (arts. 389, 395 e 404 do CC/02 e princípio da reparação integral).

Diante da diversidade de casos que versam sobre o presente artigo, é conveniente delimitar o exame de julgados a fim de se adequar ao propósito deste trabalho, razão pela qual foram eleitos três julgados para análise.

0 primeiro caso refere-se ao Recurso Especial $n^{0} 1.321 .614-S P^{65}$ da $3^{3}$ Turma do Superior Tribunal de Justiça, relatado originariamente pelo Ministro Paulo

65 “RECURSO ESPECIAL. CIVIL. AÇÃO REVISIONAL DE CONTRATO DE COMPRA E VENDA. DÓLAR AMERICANO. MAXIDESVALORIZAÇÃO DO REAL. AQUISIÇÃO DE EQUIPAMENTO PARA ATIVIDADE PROFISSIONAL. AUSÊNCIA DE RELAÇÃO DE CONSUMO. TEORIAS DA IMPREVISÃO. TEORIA DA ONEROSIDADE EXCESSIVA. TEORIA DA BASE OBJETIVA. INAPLICABILIDADE. 1. Ação proposta com a finalidade de, após a maxidesvalorização do real em face do dólar americano, ocorrida a partir de janeiro de 1999, modificar cláusula de contrato de compra e venda, com reserva de domínio, de equipamento médico (ultrassom), utilizado pelo autor no exercício da sua atividade profissional de médico, para que, afastada a indexação prevista, fosse observada a moeda nacional. 2. Consumidor é toda pessoa física ou jurídica que adquire ou utiliza, como destinatário final, produto ou serviço oriundo de um fornecedor. Por sua vez, destinatário final, segundo a teoria subjetiva ou finalista, adotada pela Segunda Seção desta Corte Superior, é aquele que ultima a atividade econômica, ou seja, que retira de circulação do mercado o bem ou o serviço para consumi-lo, suprindo uma necessidade ou satisfação própria, não havendo, portanto, a reutilização ou o reingresso dele no processo produtivo. Logo, a relação de consumo (consumidor final) não pode ser confundida com relação de insumo (consumidor intermediário). Inaplicabilidade das regras protetivas do Código de Defesa do Consumidor. 3. A intervenção do Poder Judiciário nos contratos, à luz da teoria da imprevisão ou da teoria da onerosidade excessiva, exige a demonstração de mudanças supervenientes das circunstâncias iniciais vigentes à época da realização do negócio, oriundas de evento imprevisível (teoria da imprevisão) e de evento imprevisível e extraordinário (teoria da onerosidade excessiva), que comprometa o valor da prestação, demandando tutela jurisdicional específica. 4. O histórico inflacionário e as sucessivas mo dificações no padrão monetário experimentados pelo país desde longa data até julho de 1994, quando sobreveio o Plano Real, seguido de período de relativa estabilidade até a maxidesvalorização do real em 
de Tarso Sanseverino e de relatoria para o acórdão pelo Ministro Ricardo Villas Bôas Cueva, julgado em 16.12.2014, publicado no Dário de Justiça Eletrônico em 3.3.2015, constante do Informativo de Jurisprudência no 556, de 23.2.2015 a 4.3.2015, do STJ.

Consta dos autos que o autor, recorrente, é um profissional médico que celebrou contrato de compra e venda com reserva de domínio de equipamento médico importado denominado "Ultra-som logic 400", em moeda estrangeira, com previsão de pagamento em dólar, com a empresa ré, em que se pretendeu a revisão contratual para corrigir os efeitos da maxidesvalorização do dólar, ocorrida em janeiro de 1999, sobre o contrato em questão.

A discussão do recurso especial em exame situa-se em torno da possibilidade de revisão de contrato de financiamento, celebrado em moeda estrangeira, para aquisição desse equipamento médico utilizado na atividade profissional do recorrente, cujas prestações sofreram acentuada elevação em face da maxidesvalorização do real ante o dólar ocorrida em janeiro de 1999, com pedido de modificação de cláusula contratual requerendo que se promovesse a indexação das parcelas mediante conversão para moeda nacional, com observância do Índice Nacional de Preços ao Consumidor - INPC e incidência de juros legais.

Duas questões controvertidas foram apontadas como relevantes pelo Superior Tribunal de Justiça para análise:

a) a incidência ou não do CDC sobre a relação contratual estabelecida entre as partes;

b) a possibilidade ou não de aplicação da teoria da base objetiva para corrigir os efeitos da maxidesvalorização do dólar ocorrida em janeiro de 1999.

Por maioria, a Terceira Turma decidiu negar provimento ao recurso especial nos termos do voto do Ministro Ricardo Villas Bôas Cueva, restando vencido o

\footnotetext{
face do dólar americano, ocorrida a partir de janeiro de 1999, não autorizam concluir pela imprevisibilidade desse fato nos contratos firmados com base na cotação da moeda norte-americana, em se tratando de relação contratual paritária. 5. A teoria da base objetiva, que teria sido introduzida em nosso ordenamento pelo art. 6으, inciso V, do Código de Defesa do Consumidor - CDC, difere da teoria da imprevisão por prescindir da previsibilidade de fato que determine oneração excessiva de um dos contratantes. Tem por pressuposto a premissa de que a celebração de um contrato ocorre mediante consideração de determinadas circunstâncias, as quais, se modificadas no curso da relação contratual, determinam, por sua vez, consequências diversas daquelas inicialmente estabelecidas, com repercussão direta no equilíbrio das obrigações pactuadas. Nesse contexto, a intervenção judicial se daria nos casos em que o contrato fosse atingido por fatos que comprometessem as circunstâncias intrínsecas à formulação do vínculo contratual, ou seja, sua base objetiva. 6 . Em que pese sua relevante inovação, tal teoria, ao dispensar, em especial, o requisito de imprevisibilidade, foi acolhida em nosso ordenamento apenas para as relações de consumo, que demandam especial proteção. Não se admite a aplicação da teoria do diálogo das fontes para estender a todo direito das obrigações regra incidente apenas no microssistema do direito do consumidor, mormente com a finalidade de conferir amparo à revisão de contrato livremente pactuado com observância da cotação de moeda estrangeira. 7. Recurso especial não provido".
} 
Ministro Paulo de Tarso Sanseverino, sendo que votaram com o ministro relator para o acórdão (presidente) os ministros Marco Aurélio Bellizze, Moura Ribeiro e João Otávio de Noronha.

No voto do relator originário, o Ministro Paulo de Tarso Sanseverino entendeu que ao caso deveria ser aplicada a teoria subjetiva ou finalista, posição consolidada no âmbito dessa Corte, em que o "destinatário final" seria apenas aquele que seja vulnerável e hipossuficiente, ou seja, em que somente o destinatário fático e econômico do bem pode ser considerado destinatário final, ficando excluídos os profissionais.

Dessa feita, afastou a aplicação das normas do Código de Defesa do Consumidor sob o argumento de que "o equipamento médico (sistema de ultra-som Logic 400), objeto do contrato, foi adquirido para ser utilizado em sua atividade profissional", remetendo a solução da controvérsia ao Código Civil de 1916, vigente à época.

Ressaltou que a teoria da base objetiva foi aplicada pelo STJ a fatos ocorridos antes da vigência do CDC e em benefício do fornecedor, construtoras, que diziam respeito a fatos ocorridos na vigência do Plano Cruzado (1986), ocasião em que se proibiu a inserção de cláusulas de atualização monetária das prestações mesmo em contratos de longa duração, de modo que como os contratos de promessa de compra e venda de imóveis em construção, celebrados por prazo longo, não continham cláusula de correção monetária, as prestações permaneceram congeladas em seu valor nominal, tornando-se gradualmente de valor insignificante (STJ, 4a T., REsp no 135.151/RJ, ${ }^{66}$ Rel. Min. Ruy Rosado, j. 8.10.1997, pub. 10.11.1997; e STJ, 4a T., REsp no 94.692/RJ, ${ }^{67}$ Rel. Min. Sálvio de Figueiredo Teixeira, j. 25.6.1998. DJ, 21 set. 1998. p. 167).

\footnotetext{
"Promessa de compra e venda. Fato superveniente. Ação de modificação do contrato. Plano cruzado. Correção monetária. Celebrado o contrato de promessa de compra e venda, com prestações diferidas, sem cláusula de correção monetária, durante o tempo de vigência do plano cruzado, quando se esperava debelada a inflação, a superveniente desvalorização da moeda justifica a revisão do contrato, cuja base objetiva ficou substancialmente alterada, para atualizar as prestações de modo a refletir a inflação acontecida depois da celebração do negócio. Precedente. Recurso conhecido e provido" (STJ, 4ª T. REsp no 135.151/ RJ. Rel. Min. Ruy Rosado, j. 8.10.1997, pub. 10.11.1997).

67 “CIVIL. PROMESSA DE COMPRA E VENDA. AÇÃO DE REVISÃO DO CONTRATO. CORREÇÃO MONETÁRIA. NÃOPACTUAÇÃO. IRRELEVÂNCIA. FATO SUPERVENIENTE. PLANO CRUZADO. PRECEDENTES DA TURMA. DISSÍDIO. CARACTERIZADO. RECURSO PROVIDO. PROCEDÊNCIA DO PEDIDO. I - Nos termos do entendimento da Turma, "celebrado o contrato de promessa de compra e venda, com prestações diferidas, sem cláusula de correção monetária, durante o tempo de vigência do plano Cruzado, quando se esperava debelada a inflação, a superveniente desvalorização da moeda justifica a revisão do contrato, cuja base objetiva ficou substancialmente alterada, para atualizar as prestações de modo a refletir a inflação acontecida depois da celebração do negócio' (REsp no 135.151-RJ). II - Sendo a correção monetária mero mecanismo para evitar a corrosão do poder aquisitivo da moeda, sem qualquer acréscimo do valor original, impõe-se que o valor devido seja atualizado, mesmo nos casos de não constar do contrato cláusula específica. III - É entendimento consolidado da Corte que a evolução dos fatos econômicos tornou insustentável a não-incidência da correção monetária, sob pena de prestigiar-se o enriquecimento sem causa do devedor, constituindo ela imperativo econômico, jurídico e ético indispensável à plena indenização dos danos e ao fiel e completo adimplemento das obrigações" (STJ, $4^{\mathrm{a}}$ T. REsp no 94.692/RJ. Rel. Min. Sálvio de Figueiredo Teixeira, j. 25.6.1998. DJ, 21 set. 1998. p. 167).
} 
Lembrou, ainda, que na vigência do CDC os principais casos de aplicação dessa teoria foram as hipóteses de maxidesvalorização do dólar ocorrida em janeiro de 1999, como é o caso em análise, nas quais houve a aplicação do CDC, distribuindo-se equitativamente as perdas ensejadas por esse fenômeno econômico, citando dois precedentes ${ }^{68}$ da Corte.

Concluiu dizendo que "como a teoria da base objetiva foi aplicada por esta Corte em fatos anteriores ao CDC e em detrimento do consumidor, nada impede que também seja aplicada neste caso", ou seja, posicionou-se contrário à aplicação do CDC ao caso em tela, porém defendeu a aplicação da teoria da base objetiva para solucionar a questão posta, razão pela qual votou no sentido de dar parcial provimento ao recurso especial para julgar parcialmente procedente a ação revisional, determinando que a correção monetária do contrato de arrendamento mercantil ocorresse, a partir de 19.1.1999, por metade da variação cambial contratada.

Por sua vez, o Ministro Ricardo Villas Bôas Cueva, em seu voto-vista, defendeu igualmente a inaplicabilidade do CDC e por isso fixou a controvérsia na revisão contratual em relação paritária, com observância das disposições contidas no Código Civil, concluindo que na relação contratual a regra é a observância "do princípio pacta sunt servanda, segundo o qual o contrato faz lei entre as partes e, por conseguinte, impõe ao Estado o dever de não intervir nas relações privadas", e que "o princípio da autonomia da vontade confere aos contratantes ampla

68 “CIVIL. ARRENDAMENTO MERCANTIL. CONTRATO COM CLÁUSULA DE REAJUSTE PELA VARIAÇÃO CAMBIAL. VALIDADE. ELEVAÇÃO ACENTUADA DA COTAÇÃO DA MOEDA NORTE-AMERICANA. FATO NOVO. ONEROSIDADE EXCESSIVA AO CONSUMIDOR. REPARTIÇÃO DOS ÔNUS. LEI N. 8.880/94, ART. 6‥ CDC, ART. 6ำ V. I. Não é nula cláusula de contrato de arrendamento mercantil que prevê reajuste das prestações com base na variação da cotação de moeda estrangeira, eis que expressamente autorizada em norma legal específica (art. 6으 da Lei n. 8.880/94). Il. Admissível, contudo, a incidência da Lei n. 8.078/90, nos termos do art. 6ㅇ, V, quando verificada, em razão de fato superveniente ao pacto celebrado, consubstanciado, no caso, por aumento repentino e substancialmente elevado do dólar, situação de onerosidade excessiva para o consumidor que tomou o financiamento. III. Índice de reajuste repartido, a partir de 19.01.99 inclusive, eqüitativamente, pela metade, entre as partes contratantes, mantida a higidez legal da cláusula, decotado, tão somente, o excesso que tornava insuportável ao devedor o adimplemento da obrigação, evitando-se, de outro lado, a total transferência dos ônus ao credor, igualmente prejudicado pelo fato econômico ocorrido e também alheio à sua vontade. IV. Recurso especial conhecido e parcialmente provido" (STJ, 2 ${ }^{a}$ S. REsp no 473.140/SP. Rel. Min. Carlos Alberto Menezes Direito, Red. p/ acordão Min. Aldir Passarinho Júnior, j. 12.2.2003, pub. 4.8.2003); “PROCESSO CIVIL - RECURSO ESPECIAL - AGRAVO REGIMENTAL - ARRENDAMENTO MERCANTIL - AÇÃO REVISIONAL - REAJUSTE - VARIAÇÃO CAMBIAL DE MOEDA ESTRANGEIRA - LEGALIDADE - ART. 6" DA LEI 8.880/94 - ONEROSIDADE EXCESSIVA - DIVISÃO DOS ENCARGOS EM PARTES IDÊNTICAS - DESPROVIMENTO. 1 - É lícita a cláusula de contrato de arrendamento mercantil que prevê reajuste das prestações com base na variação da cotação de moeda estrangeira, eis que expressamente autorizada em norma legal específica (art. 6º, da Lei n. 8.880/94). 2 - Com relação à matéria relativa à variação cambial nos contratos de arrendamento mercantil, a Eg. Segunda Seção desta Corte pacificou o entendimento no sentido da divisão, em partes idênticas, dos encargos decorrentes da abrupta mudança ocorrida na cotação da moeda norte-americana entre arrendante e arrendatário a partir de janeiro de 1999. Precedente (REsp 472.594/SP). 3 - Agravo regimental desprovido" (STJ, Quarta Turma. AgRg no REsp no 841.370/DF. Rel. Min. Jorge Scartezzini, j. 17.8.2006. DJ, 18 set. 2006. p. 334). 
liberdade para estipular o que Ihes convenha desde que preservada a moral, a ordem pública e os bons costumes, valores que não podem ser derrogados pelas partes".

Portanto, à hipótese, no seu entendimento, só seria possível revisar o contrato entabulado em caso de imprevisão e onerosidade excessiva, figuras presentes no CC, que exigem a

demonstração de mudanças supervenientes das circunstâncias iniciais vigentes à época da realização do negócio, oriundas de evento imprevisível (teoria da imprevisão) e de evento imprevisível e extraordinário (teoria da onerosidade excessiva), que comprometam o valor da prestação.

Acabou por entender não ser possivel afastar a previsibilidade de risco ao caso por força da "escolha decorrente da celebração de contrato firmado em moeda estrangeira", que não é de curso forçado, "tendo em vista a relação jurídica paritária e as oscilações econômicas relatadas".

Ao apreciar a teoria da base objetiva ou da base do negócio jurídico, pontuou que essa teoria "difere da teoria da imprevisão por prescindir da previsibilidade de fato que determine oneração excessiva de um dos contratantes", com repercussão direta no equilíbrio das obrigações pactuadas.

Nesse ponto, cabe mencionar suas palavras:

[...] tal teoria, ao dispensar, em especial, o requisito de imprevisibilidade, foi acolhida em nosso ordenamento apenas para as relações de consumo, que demandam especial proteção. Não se admite a aplicação da teoria do diálogo das fontes para estender a todo direito das obrigações regra incidente apenas no microssistema do direito do consumidor. De outro modo, a teoria da quebra da base objetiva poderia ser invocada para revisão ou resolução de qualquer contrato no qual haja modificação das circunstâncias iniciais, ainda que previsíveis, comprometendo em especial o princípio pacta sunt servanda e, por conseguinte, a segurança jurídica.

Acrescenta, ainda, que permitir essa interface prejudicaria aquele "que teria, em tese, algum benefício com a superveniência de fatos que atinjam a base do negócio" e arremata dizendo que o critério seria examinar se a alteração ocorrida na base do contrato superaria o "risco inerente à natureza da avença". Assenta seu posicionamento aduzindo que a repactuação da avença entre as partes já em um ambiente econômico de maxidesvalorização do real em face da moeda americana 
representaria, de certo modo, a incorporação do fato que teria ocasionado algum desequilíbrio, tornando a hipótese de simples inadimplência.

Portanto, votou no sentido de negar provimento ao recurso especial, sendo acompanhado pelos demais ministros João Otávio de Noronha, Marco Aurélio Bellizze e Moura Ribeiro.

Assim, observam-se duas linhas de raciocínio, a do Ministro Paulo de Tarso Sanseverino que, apesar de ter afastado a aplicação do CDC ao caso posto, entendeu pela utilização da teoria da base objetiva, própria do regime consumerista, para dar solução mais equânime, repartindo o prejuízo entre as partes, enquanto que a tese vencedora do Ministro Ricardo Villas Bôas Cueva, ao afastar a aplicação do CDC, entendeu não ser possível a interface entre o CC e o CDC, devendo o pedido de revisão contratual ser apreciado com base nas teorias da imprevisão e da onerosidade excessiva, próprias do regime comum, terminando por entender pela ausência do requisito da imprevisibilidade e extraordinariedade, o que obstou a revisão pleiteada.

A questão poderia ter sido resolvida com base no entendimento firmado pela própria Corte Superior no sentido de admitir a mitigação da teoria finalista para autorizar a incidência do Código de Defesa do Consumidor nas hipóteses em que a parte (pessoa física ou jurídica), apesar de não ser destinatária final do produto ou serviço, apresenta-se em situação de vulnerabilidade, constante do seu Informativo de Jurisprudência no 510 , de 18.12.2012, ${ }^{69}$ que é anterior ao

69 “DIREITO DO CONSUMIDOR. CONSUMO INTERMEDIÁRIO. VULNERABILIDADE. FINALISMO APROFUNDADO. Não ostenta a qualidade de consumidor a pessoa física ou jurídica que não é destinatária fática ou econômica do bem ou serviço, salvo se caracterizada a sua vulnerabilidade frente ao fornecedor. A determinação da qualidade de consumidor deve, em regra, ser feita mediante aplicação da teoria finalista, que, numa exegese restritiva do art. $2^{\circ}$ do $\mathrm{CDC}$, considera destinatário final tão somente o destinatário fático e econômico do bem ou serviço, seja ele pessoa física ou jurídica. Dessa forma, fica excluído da proteção do CDC o consumo intermediário, assim entendido como aquele cujo produto retorna para as cadeias de produção e distribuição, compondo o custo (e, portanto, o preço final) de um novo bem ou serviço. Vale dizer, só pode ser considerado consumidor, para fins de tutela pelo CDC, aquele que exaure a função econômica do bem ou serviço, excluindo-o de forma definitiva do mercado de consumo. Todavia, a jurisprudência do STJ, tomando por base o conceito de consumidor por equiparação previsto no art. 29 do CDC, tem evoluído para uma aplicação temperada da teoria finalista frente às pessoas jurídicas, num processo que a doutrina vem denominando 'finalismo aprofundado'. Assim, tem se admitido que, em determinadas hipóteses, a pessoa jurídica adquirente de um produto ou serviço possa ser equiparada à condição de consumidora, por apresentar frente ao fornecedor alguma vulnerabilidade, que constitui o princípio-motor da política nacional das relações de consumo, premissa expressamente fixada no art. $4^{\circ}, \mathrm{I}$, do $\mathrm{CDC}$, que legitima toda a proteção conferida ao consumidor. A doutrina tradicionalmente aponta a existência de três modalidades de vulnerabilidade: técnica (ausência de conhecimento específico acerca do produto ou serviço objeto de consumo), jurídica (falta de conhecimento jurídico, contábil ou econômico e de seus reflexos na relação de consumo) e fática (situações em que a insuficiência econômica, física ou até mesmo psicológica do consumidor o coloca em pé de desigualdade frente ao fornecedor). Mais recentemente, tem se incluído também a vulnerabilidade informacional (dados insuficientes sobre o produto ou serviço capazes de in fluenciar no processo decisório de compra). Além disso, a casuística poderá apresentar novas formas de vulnerabilidade aptas a atrair a incidência do CDC à relação de consumo. Numa relação interempresarial, 
julgado em exame (precedentes AgRg no AREsp no 601.234/DF; AgRg no AREsp no 415.244/SC; AgRg no AREsp no 415.244/SC; REsp no 567.192/SP; AgRg no AREsp no 426.563/PR; AgRg no REsp no 1.413.889/SC; AgRg no AREsp no 439.263/SP, e EDcl no AREsp no 265.845/SP).

Em outras palavras, pelo critério da vulnerabilidade, o CDC poderia ter sido aplicado ao caso, tendo em vista que um médico face o fornecedor do produto que adquiriu para poder exercer sua atividade profissional, longe de ser aquela atividade lucrativa para a qual as empresas investem seu capital em insumo a fim de atingir maior chance de ganho no mercado, não se mostra em condições de igualdade em relação ao fabricante do equipamento.

Com a incidência do CDC ao caso, bastaria aplicar a teoria da base do negócio para viabilizar a revisão contratual a fim de restabelecer o equilíbrio entre as partes.

Por outro lado, mesmo em caso de afastamento do CDC pela teoria finalista, não se pode negligenciar que o fato em questão impactou diretamente no equilíbrio econômico do contrato, de modo a prejudicar sobremaneira o profissional médico, abalando a relação de igualdade que se presumiu haver entre as partes.

Ademais, o próprio princípio da função social do contrato, que reforça o princípio de conservação do contrato e que assegura trocas úteis, justas e legítimas, ${ }^{70}$ daria conta de encontrar a solução mais adequada ao caso, conservando-se o contrato a fim de possibilitar ao médico o atendimento a seus pacientes e mitigar o prejuízo entre as partes.

Com base no princípio do equilíbrio econômico do contrato, novo princípio contratual, comum ao $\mathrm{CDC}$ e portanto a ponte da interface entre o regime comum e o regime consumerista, o intérprete poderia ter se utilizado da teoria da base do negócio jurídico prevista no art. 6ㅇ inc. V do CDC para corrigir os efeitos da maxidesvalorização do dólar ocorrida em janeiro de 1999, em uma análise com coerência sistemática e valorativa, até porque a norma consumerista decorre de mandamento constitucional, sendo a Constituição Federal a Lei Maior a nortear todo o sistema jurídico.

para além das hipóteses de vulnerabilidade já consagradas pela doutrina e pela jurisprudência, a relação de dependência de uma das partes frente à outra pode, conforme o caso, caracterizar uma vulnerabilidade legitimadora da aplicação do CDC, mitigando os rigores da teoria finalista e autorizando a equiparação da pessoa jurídica compradora à condição de consumidora. Precedentes citados: REsp no 1.196.951-PI, DJe 9/4/2012, e REsp 1.027.165-ES, DJe 14/6/2011" (REsp no 1.195.642-RJ, 3a Turma. Rel. Min. Nancy Andrighi, j. 13.11.2012).

70 I Jornada de Direito Civil, Enunciado no 22 - “Art. 421: A função social do contrato, prevista no art. 421 do novo Código Civil, constitui cláusula geral que reforça o princípio de conservação do contrato, assegurando trocas úteis e justas". 
O segundo caso refere-se ao Recurso Especial $n^{0}$ 955.134-SC, ${ }^{71}$ da $4^{\text {a }}$ Turma do STJ, relatado pelo Ministro Luis Felipe Salomão, julgado em 16.8.2012 por votação unânime, publicado no Dário de Justiça Eletrônico em 29.8.2012.

Trata-se de ação judicial contra construtora em que se pleiteia a rescisão do contrato de compra e venda de uma casa nova firmado pela autora, recorrida, entregue com atraso de mais de dois anos e com diversos defeitos que a tornariam imprópria para o uso, alegando-se risco de desabamento, e a devolução dos valores pagos, sem qualquer desconto, acrescidos dos mesmos juros, correção monetária, multa, arras e comissão de corretagem que pagaria à vendedora, no distrato, se estivesse aquela inadimplente, além de pedidos sucessivos.

O ministro relator fixou três pontos controvertidos, quais sejam:

a) reconhecer a possibilidade de condenação da parte adversa (autora) ao pagamento de aluguéis pelo período de ocupação do imóvel, muito embora tenha o acórdão recorrido firmado a premissa de que a

71 "DIREITO DO CONSUMIDOR E PROCESSUAL CIVIL. RECURSO ESPECIAL. CONTRATO DE PROMESSA DE COMPRA E VENDA DE IMÓVEL. RESCISÃO POR CULPA DA CONSTRUTORA (VENDEDOR). DEFEITOS DE CONSTRUÇÃO. ARBITRAMENTO DE ALUGUÉIS EM RAZÃO DO USO DO IMÓVEL. POSSIBILIDADE. PAGAMENTO, A TÍTULO DE SUCUMBÊNCIA, DE LAUDO CONFECCIONADO EXTRAJUDICIALMENTE PELA PARTE VENCEDORA. DESCABIMENTO. EXEGESE DOS ARTS. 19 E 20 DO CPC. INVERSÃO DE CLÁUSULA CONTRATUAL QUE PREVIA MULTA EXCLUSIVAMENTE EM BENEFÍCIO DO FORNECEDOR, PARA A HIPÓTESE DE MORA OU INADIMPLEMENTO DO CONSUMIDOR. POSSIBILIDADE. 1. Apesar de a rescisão contratual ter ocorrido por culpa da construtora (fornecedor), é devido o pagamento de aluguéis, pelo adquirente (consumidor), em razão do tempo em que este ocupou o imóvel. O pagamento da verba consubstancia simples retribuição pelo usufruto do imóvel durante determinado interregno temporal, rubrica que não se relaciona diretamente com danos decorrentes do rompimento da avença, mas com a utilização de bem alheio. Daí por que se mostra desimportante indagar quem deu causa à rescisão do contrato, se o suporte jurídico da condenação é a vedação do enriquecimento sem causa. Precedentes. 2. Seja por princípios gerais do direito, seja pela principiologia adotada no Código de Defesa do Consumidor, seja, ainda, por comezinho imperativo de equidade, mostra-se abusiva a prática de se estipular penalidade exclusivamente ao consumidor, para a hipótese de mora ou inadimplemento contratual, ficando isento de tal reprimenda o fornecedor - em situações de análogo descumprimento da avença. Assim, prevendo o contrato a incidência de multa moratória para o caso de descumprimento contratual por parte do consumidor, a mesma multa deverá incidir, em reprimenda do fornecedor, caso seja deste a mora ou o inadimplemento. Assim, mantém-se a condenação do fornecedor - construtor de imóveis - em restituir integralmente as parcelas pagas pelo consumidor, acrescidas de multa de $2 \%$ (art. 52, $1^{1}$,,$C D C$ ), abatidos os aluguéis devidos, em vista de ter sido aquele, o fornecedor, quem deu causa à rescisão do contrato de compra e venda de imóvel. 3. Descabe, porém, estender em benefício do consumidor a cláusula que previa, em prol do fornecedor, a retenção de valores a título de comissão de corretagem e taxa de serviço, uma vez que os mencionados valores não possuem natureza de cláusula penal moratória, mas indenizatória. 4.0 art. 20 , caput e $\S 2^{\circ}$, do Código de Processo Civil enumera apenas as consequências da sucumbência, devendo o vencido pagar ao vencedor as 'despesas' que este antecipou, não alcançando indistintamente todos os gastos realizados pelo vencedor, mas somente aqueles 'endoprocessuais' ou em razão do processo, quais sejam, 'custas dos atos do processo', 'a indenização de viagem, diária de testemunha e remuneração do assistente técnico'. Assim, descabe o ressarcimento, a título de sucumbência, de valores despendidos pelo vencedor com a confecção de laudo extrajudicial, mediante a contratação de perito de sua confiança. Precedentes. 5. Recurso especial parcialmente provido". 
construtora foi a causadora do rompimento contratual; b) condenação imposta aos recorrentes em custear laudo de vistoria confeccionado pela autora extrajudicialmente, aplicando o Tribunal a quo, por analogia, o art. 20, $\S 2^{\circ}$, do Código de Processo Civil, referente a despesas processuais, e c) inversão de encargos que, contratualmente, só beneficiavam o fornecedor, na hipótese de mora/inadimplemento do consumidor, no caso, a imposição de multa moratória, retenção de $5 \%$ (cinco por cento) a título de comissão de corretagem e de $2 \%$ (dois por cento) a título de taxa de serviço.

Ficaremos adstritos ao terceiro ponto. Entendeu o ministro que, de fato, no CDC não há previsão expressa de possibilidade de inversão, em benefício do consumidor, de cláusula penal que amparava com exclusividade o fornecedor. Contudo, posiciona-se no sentido de que o "espírito do Codex, de forma eloquente, informa ser imperiosa a adoção dessa providência”.

Elucida que o CDC se utilizou da técnica de cláusulas abertas para tratar das práticas e cláusulas abusivas, de modo a trazer em seu texto mero rol exemplificativo para concebê-las contido em seus arts. $39^{72}$ e $51 .^{73}$

72 “Art. 39. É vedado ao fornecedor de produtos ou serviços, dentre outras práticas abusivas: I - condicionar o fornecimento de produto ou de serviço ao fornecimento de outro produto ou serviço, bem como, sem justa causa, a limites quantitativos; II - recusar atendimento às demandas dos consumidores, na exata medida de suas disponibilidades de estoque, e, ainda, de conformidade com os usos e costumes; III - enviar ou entregar ao consumidor, sem solicitação prévia, qualquer produto, ou fornecer qualquer serviço; IV - prevalecer-se da fraqueza ou ignorância do consumidor, tendo em vista sua idade, saúde, conhecimento ou condição social, para impingir-lhe seus produtos ou serviços; $V$ - exigir do consumidor vantagem manifestamente excessiva; VI - executar serviços sem a prévia elaboração de orçamento e autorização expressa do consumidor, ressalvadas as decorrentes de práticas anteriores entre as partes; VII - repassar informação depreciativa, referente a ato praticado pelo consumidor no exercício de seus direitos; VIII - colocar, no mercado de consumo, qualquer produto ou serviço em desacordo com as normas expedidas pelos órgãos oficiais competentes ou, se normas específicas não existirem, pela Associação Brasileira de Normas Técnicas ou outra entidade credenciada pelo Conselho Nacional de Metrologia, Normalização e Qualidade Industrial (Conmetro); IX - recusar a venda de bens ou a prestação de serviços, diretamente a quem se disponha a adquiri-los mediante pronto pagamento, ressalvados os casos de intermediação regulados em leis especiais; X - elevar sem justa causa o preço de produtos ou serviços. XI - Dispositivo incluído pela MPV no 1.890-67, de 22.10.1999, transformado em inciso XIII, quando da conversão na Lei no 9.870, de 23.11.1999 XII - deixar de estipular prazo para o cumprimento de sua obrigação ou deixar a fixação de seu termo inicial a seu exclusivo critério. XIII - aplicar fórmula ou índice de reajuste diverso do legal ou contratualmente estabelecido. Parágrafo único. Os serviços prestados e os produtos remetidos ou entregues ao consumidor, na hipótese prevista no inciso III, equiparam-se às amostras grátis, inexistindo obrigação de pagamento".

73 “Art. 51. São nulas de pleno direito, entre outras, as cláusulas contratuais relativas ao fornecimento de produtos e serviços que: I - impossibilitem, exonerem ou atenuem a responsabilidade do fornecedor por vícios de qualquer natureza dos produtos e serviços ou impliquem renúncia ou disposição de direitos. Nas relações de consumo entre o fornecedor e o consumidor pessoa jurídica, a indenização poderá ser limitada, em situações justificáveis; II - subtraiam ao consumidor a opção de reembolso da quantia já paga, nos casos previstos neste código; III - transfiram responsabilidades a terceiros; IV - estabeleçam obrigações consideradas iníquas, abusivas, que coloquem o consumidor em desvantagem exagerada, 
Menciona que o CDC deve ser interpretado à luz do seu art. 4ํㅜ, por estabelecer objetivos da política nacional das relações de consumo e princípios que devem ser respeitados, destacando a "harmonia das relações de consumo" e o "equilíbrio nas relações entre consumidores e fornecedores", ${ }^{74}$ além de outros direitos não previstos no CDC, mas que derivem "dos princípios gerais de direito" e da "equidade" (art. 7으).

Cita, ainda, o art. 51 do mesmo diploma legal que:

deixa claro que nos contratos de consumo deve haver reciprocidade de direitos entre fornecedores e consumidores, mostrando-se abusivas, por exemplo, as cláusulas contratuais que: IX - deixem ao fornecedor a opção de concluir ou não o contrato, embora obrigando o consumidor; XI - autorizem o fornecedor a cancelar o contrato unilateralmente, sem que igual direito seja conferido ao consumidor; XII - obriguem o consumidor a ressarcir os custos de cobrança de sua obrigação, sem que igual direito Ihe seja conferido contra o fornecedor.

ou sejam incompatíveis com a boa-fé ou a eqüidade; V - (Vetado); VI - estabeleçam inversão do ônus da prova em prejuízo do consumidor; VII - determinem a utilização compulsória de arbitragem; VIII - imponham representante para concluir ou realizar outro negócio jurídico pelo consumidor; IX - deixem ao fornecedor a opção de concluir ou não o contrato, embora obrigando o consumidor; X - permitam ao fornecedor, direta ou indiretamente, variação do preço de maneira unilateral; XI - autorizem o fornecedor a cancelar o contrato unilateralmente, sem que igual direito seja conferido ao consumidor; XII - obriguem o consumidor a ressarcir os custos de cobrança de sua obrigação, sem que igual direito Ihe seja conferido contra o fornecedor; XIII - autorizem o fornecedor a modificar unilateralmente o conteúdo ou a qualidade do contrato, após sua celebração; XIV - infrinjam ou possibilitem a violação de normas ambientais; XV - estejam em desacordo com o sistema de proteção ao consumidor; XVI - possibilitem a renúncia do direito de inde-

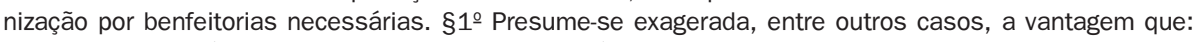
I - ofende os princípios fundamentais do sistema jurídico a que pertence; II - restringe direitos ou obrigações fundamentais inerentes à natureza do contrato, de tal modo a ameaçar seu objeto ou equilíbrio contratual; III - se mostra excessivamente onerosa para o consumidor, considerando-se a natureza e conteúdo do contrato, o interesse das partes e outras circunstâncias peculiares ao caso. §2ำ A nulidade de uma cláusula contratual abusiva não invalida o contrato, exceto quando de sua ausência, apesar dos esforços de integração, decorrer ônus excessivo a qualquer das partes. §3o (Vetado). §4ํㅡ É facultado a qualquer consumidor ou entidade que o represente requerer ao Ministério Público que ajuíze a competente ação para ser declarada a nulidade de cláusula contratual que contrarie o disposto neste código ou de qualquer forma não assegure o justo equilíbrio entre direitos e obrigações das partes".

74 “Art. 4ํA Política Nacional das Relações de Consumo tem por objetivo o atendimento das necessidades dos consumidores, o respeito à sua dignidade, saúde e segurança, a proteção de seus interesses econômicos, a melhoria da sua qualidade de vida, bem como a transparência e harmonia das relações de consumo, atendidos os seguintes princípios: [...] III - harmonização dos interesses dos participantes das relações de consumo e compatibilização da proteção do consumidor com a necessidade de desenvolvimento econômico e tecnológico, de modo a viabilizar os princípios nos quais se funda a ordem econômica (art. 170, da Constituição Federal), sempre com base na boa-fé e equilíbrio nas relações entre consumidores e fornecedores; [...]. Art. 6ㅇ São direitos básicos do consumidor: [...] II - a educação e divulgação sobre o consumo adequado dos produtos e serviços, asseguradas a liberdade de escolha e a igualdade nas contratações". 
Para corroborar sua fundamentação, chama à atenção a Portaria № 4, de 13.3.1998, da Secretaria de Direito Econômico do Ministério da Justiça (SDE/MJ), que previu como abusivas, entre outras, sendo nulas de pleno direito, as cláusulas que "6. estabeleçam sanções, em caso de atraso ou descumprimento da obrigação, somente em desfavor do consumidor", inserindo-se na categoria de outros direitos "decorrentes [...] de regulamentos expedidos pelas autoridades administrativas competentes" (art. $7^{\circ}$ do $C D C$ ), e ressalta a tendência mundial "de se exigir reciprocidade entre as penalidades impostas ao consumidor e ao fornecedor, tendo sido adotada na Diretiva n. 93/13, do Conselho da Comunidade Econômica Europeia (CEE), de 05 de abril de 1993, nos termos do art. 1ํ, alínea 'd'”:

1. Cláusulas que têm como objetivo ou como efeito: [...] d) Permitir ao profissional reter montantes pagos pelo consumidor se este renunciar à celebração ou execução do contrato, sem prever o direito de o consumidor receber do profissional uma indenização de montante equivalente se for este a renunciar [...].

Arremata dizendo que, com base nos princípios gerais do direito, na principiologia adotada no CDC e por imperativo de equidade, revela-se "abusiva a prática de se estipular penalidade exclusivamente ao consumidor, para a hipótese de mora ou inadimplemento contratual, ficando isento de tal reprimenda o fornecedor - em situações análogas", razão pela qual conclui que "prevendo o contrato a incidência de multa moratória para o caso de descumprimento contratual por parte do consumidor, a mesma multa deverá incidir, em reprimenda do fornecedor, caso seja deste a mora ou o inadimplemento".

Do caso em tela extrai-se a seguinte questão: a inexistência de cláusula contratual representaria óbice ao dever de reciprocidade de direitos e ao princípio do equilíbrio contratual, notadamente em contrato de adesão?

De acordo com a solução jurídica construída pelo Superior Tribunal de Justiça, a inexistência de cláusula contratual não representaria óbice ao dever de reciprocidade de direitos e ao princípio do equilíbrio contratual.

Contudo, o Tribunal de Justiça de São Paulo sumulou ${ }^{75}$ entendimento no sentido de ser inadmissível a condenação da vendedora ao pagamento de multa ajustada apenas para a hipótese de mora do comprador, afastando-se a aplicação da penalidade por equidade, ainda que descumprido o prazo para a entrega do

75 Ver Súmula no 159 do TJSP. 
imóvel objeto do compromisso de venda e compra, sob o argumento de que prevalece a incidência do disposto no art. 411 do Código Civil. ${ }^{76}$

Ainda, o Tribunal de Justiça do Rio de Janeiro posicionou-se no sentido de ser prática abusiva a falta de reciprocidade em relação à previsão de multa contratual, por meio da:

Súmula 335 - Revela-se abusiva a prática de se estipular penalidade exclusivamente ao consumidor, para as hipóteses de mora ou de inadimplemento contratual, sem igual imposição ao fornecedor em situações de análogo descumprimento da avença. Ref.: Processo Administrativo n‥ 0053831-70.2014.8.19.0000 - J. 04/05/2015 Rel. Des. Jesse Torres. Votação por maioria.

Portanto, ao mesmo tema, o TJSP deu prevalência ao princípio da autonomia privada, o TJRJ considerou tal prática abusiva, enquanto que o STJ, além de considerar prática abusiva, entendeu que a mesma multa moratória prevista para o caso de descumprimento contratual por parte do consumidor deveria incidir em reprimenda ao fornecedor em mora ou inadimplente.

Nesse contexto, estava instaurada a insegurança jurídica em relação ao jurisdicionado.

Todavia, em 8.5.2019, o STJ fixou as seguintes teses para os fins repetitivos nos temas nos $970^{77}$ e $971,{ }^{78}$ respectivamente: "A cláusula penal moratória tem a finalidade de indenizar pelo adimplemento tardio da obrigação, e, em regra, estabelecida em valor equivalente ao locativo, afasta-se sua cumulação com lucros cessantes"; e:

No contrato de adesão firmado entre o comprador e a construtora/ incorporadora, havendo previsão de cláusula penal apenas para o inadimplemento do adquirente, deverá ela ser considerada para a fixação da indenização pelo inadimplemento do vendedor. As obrigações heterogêneas (obrigações de fazer e de dar) serão convertidas em dinheiro, por arbitramento judicial.

76 “Art. 411. Quando se estipular a cláusula penal para o caso de mora, ou em segurança especial de outra cláusula determinada, terá o credor o arbítrio de exigir a satisfação da pena cominada, juntamente com o desempenho da obrigação principal".

77 BRASIL. Superior Tribunal de Justiça. Recurso especial nº 1.498.484 - DF, da 2a Seção do Superior Tribunal de Justiça. Brasília, DF, 8.5.2019.

78 BRASIL. Superior Tribunal de Justiça. Recurso especial $n^{\circ}$ 1.614.721- DF, da 2a Seção do Superior Tribunal de Justiça. Brasília, DF, 8.5.2019. 
Portanto, tais teses superaram o entendimento da Corte Superior, ao longo de anos, pela possibilidade de cumulação de lucros cessantes com a multa moratória.

Ao fixar a tese no sentido de que a cláusula penal moratória tem a finalidade de indenizar e não mais de punir, entendeu-se que, por ter a mesma finalidade dos lucros cessantes, a cumulação de ambos passou a ser incabível.

Note-se que, apesar de ser mantido o entendimento pela possibilidade de inversão da multa contratual prevista apenas para o inadimplemento do adquirente em desfavor do vendedor inadimplente, essa hipótese somente será aplicada se a indenização não tiver sido fixada de outro modo, como exemplo, por lucros cessantes.

Em ambos os casos, as teses foram fixadas por maioria, sendo que os ministros Nancy Andrighi e Marco Buzzi, que entenderam pela possibilidade de cumulação, foram votos vencidos em relação ao Tema oㅜ 970, e os ministros Maria Isabel Gallotti e Antonio Carlos Ferreira, que entenderam pela impossibilidade de inversão da cláusula penal estabelecida em desfavor do adquirente, foram votos vencidos em relação ao Tema no 971.

A resposta dada pelo STJ, no sentido de ser possível a inversão da multa, é a que mais se adequa ao sistema jurídico brasileiro, uma vez que, por força da vulnerabilidade do consumidor, que enseja a proteção da parte mais fraca, atrai os princípios gerais de direito, a principiologia adotada pelo CDC e o imperativo de equidade (princípio da igualdade nas contratações e da harmonia das relações de consumo) na solução do caso. Dito de outro modo, essa interpretação é necessária para corrigir a desigualdade imposta ao consumidor pelo fornecedor, afastando a aplicação do princípio da autonomia da vontade ao contrato, notadamente por se tratar de contrato de adesão em que inexiste autonomia da vontade na elaboração das cláusulas contratuais em relação ao consumidor.

É o critério da vulnerabilidade, somado ao princípio da boa-fé objetiva, que autoriza o afastamento do princípio da autonomia da vontade na hipótese aventada, bem como o princípio da igualdade nas contratações é o que fundamenta a inversão, em benefício do consumidor, de cláusula penal que amparava com exclusividade o fornecedor, não podendo ser preterido o preceito constitucional da igualdade por regra afeta unicamente ao regime das obrigações.

Em 27.12.2018, a Lei oㅜ 13.786, que alterou as leis nos 4.591, de 16.12.1964, e 6.766, de 19.12.1979, para disciplinar a resolução do contrato por inadimplemento do adquirente de unidade imobiliária em incorporação imobiliária e em parcelamento de solo urbano, ao acrescentar o art. 43-A, §2º, à Lei oㅜ 4.591/64, previu expressamente que na hipótese de atraso na entrega do imóvel será "devida ao adquirente adimplente, por ocasião da entrega da unidade, indenização de 1\% (um por cento) do valor efetivamente pago à incorporadora, para cada mês de atraso, pro rata die, corrigido monetariamente conforme índice estipulado em contrato". 
Assim, para contratos celebrados após a vigência da lei em apreço, deverá ser aplicada essa regra que fixa previamente a indenização em caso de atraso na entrega do imóvel, considerada como multa.

Oterceiroeúltimo casorefere-seà Apelaçãonº 1003041-41.2014.8.26.0236, ${ }^{79}$ da 7aㅡ Câmara de Direito Privado do Tribunal de Justiça de São Paulo, relatada pelo Desembargador Rômolo Russo, julgada em 3.8.2016 por votação unânime.

Consta dos autos que o autor pretendeu a condenação de sua operadora de plano de saúde na obrigação de fazer consistente na realização do procedimento artrose lombar (TUSS 30715016), retirada de hérnia de disco (TUSS 30715180) e enxerto ósseo (TUSS 30713072), por meio de técnica minimamente invasiva para o tratamento de sua patologia.

O relator entendeu pela aplicação do CDC à hipótese dos autos, pela possibilidade de revisão contratual, pela prática abusiva consistente na negativa de cobertura pela operadora e pela caracterização dos danos morais.

Expressamente, sobre a possibilidade de revisão dos negócios jurídicos envolvendo planos de saúde, o desembargador afirma que "tal decorre da nova feição do Direito Civil, que, relativizando a aplicação do princípio do 'pacta sunt servanda', impõe o diálogo entre a autonomia privada, a boa-fé e a função social do contrato”.

Essa, aliás, foi a solução encontrada na I Jornada de Direito Civil, sedimentada no Enunciado no 23:

Art. 421: A função social do contrato, prevista no art. 421 do novo Código Civil, não elimina o princípio da autonomia contratual, mas atenua ou reduz o alcance desse princípio quando presentes interesses metaindividuais ou interesse individual relativo à dignidade da pessoa humana.

\footnotetext{
79 “Plano de saúde. Contrato de assistência médica e/ou hospitalar. Aplicabilidade do CDC (Súmula 469 do C. STJ). Possibilidade de revisão de cláusulas contratuais que decorre do próprio sistema jurídico (arts. 478 e 480 do CC e art. 6ㅇ, V, do CDC). Relativização da 'pacta sunt servanda'. Serviços médicos e hospitalares. Diagnóstico de estenose acentuada do canal vertebral, sem melhora com tratamento clínicao. Prescrição médica positiva à realização de procedimento cirúrgico (artrodese). Negativa de cobertura fundada em cláusula contratual restritiva. Irrelevância do procedimento não constar da lista da ANS e de haver exclusão contratual. Abusividade manifesta. Conduta que implica na concreta inutilidade do negócio jurídico. Desequilíbrio contratual no exercício abusivo do direito que se evidencia na desigualdade material de poder. Prestadora que confunde boa-fé com interesse próprio. Menoscabo com o consumidor. Lesão à dignidade humana. Interpretação que fere a boa-fé objetiva e contrapõe-se à função social do contrato (arts. 421 e 422 do Cód. Civil). Conduta que a doutrina moderna caracteriza como

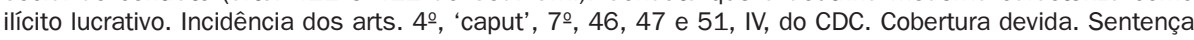
mantida. Danos morais. Negativa da prestadora de serviços à cobertura de procedimento cirúrgico que amplifica a aflição psíquica e causa situação de impotência. Necessidade da cirurgia evidenciada. Quadro de dor e déficit neurológico progressivo. Indenização cabível. Malferimento do princípio fundamental da dignidade da pessoa humana (art. 1ํ, III, CF), vértice básico do dano moral. Quantum indenizatório arbitrado em $\mathrm{R} \$ 15.000,00$. Indenização excessiva. Redução para a quantia de $\mathrm{R} \$ 10.000,00$ (dez mil reais). Plausibilidade. Recurso parcialmente provido".
} 
Cita, ainda, a chamada hipervulnerabilidade do consumidor (art. $4^{\circ}$ e inc. I do $\mathrm{CDC}$ ), a interpretação contratual mais favorável ao consumidor (art. 47 do $\mathrm{CDC}$ ), a dignidade da pessoa humana, a abusividade e desvantagem, a equidade, os deveres de colaboração, comunicação, confiança, lealdade, além da caracterização da conduta da operadora de saúde como ilícito lucrativo.

A discussão nesse julgado tratou da possibilidade de revisão de cláusulas contratuais em face do princípio pacta sunt servanda.

A partir do exame sistemático e coordenado, com fundamento no critério do favor debilis, preservou-se a coerência do sistema e os valores em jogo, observou-se o ponto de aproximação entre os regimes comum e consumerista (princípio da boa-fé objetiva) e a disposição de abertura a permitir a interface entre as normas (art. 7으, CDC), proporcionando um resultado inteligente, de forma legítima, ou seja, sem arbitrariedade.

\section{Conclusão}

A distinção entre relações paritárias e relações desiguais não é critério suficiente para definir o regime jurídico a ser aplicado à relação negocial, sobretudo porque há situações de desigualdade que igualmente são tratadas pelo Código Civil de 2002, como é o caso dos contratos de adesão, da lesão ou alteração das circunstâncias, por exemplo.

O ponto de contato entre os dois regimes são os princípios, sejam gerais ou contratuais, notadamente os chamados novos princípios consistentes na boa-fé objetiva, no equilíbrio econômico do contrato e na função social do contrato, que permitem, por meio de pontes ou cláusulas de abertura no CC e no CDC, a interface entre esses sistemas, de modo que a distinção na aplicação desses princípios revela-se na intensidade das exigências valorativas que serão responsáveis pela modulação de sua incidência e regras consequentes.

Essa constatação leva à possibilidade da coexistência das normas, respeitando-se a coerência sistemática e valorativa a nortear a atividade de coordenação e harmonização da aplicação do CC e CDC, uma vez que se mostram insuficientes os critérios clássicos de hierarquia, especialidade e cronologia para afastar a antinomia.

Esse caminho interpretativo revela-se mais adequado e em consonância com os comandos constitucionais, em meio à hipercomplexidade e pluralidade de fontes normativas em um sistema jurídico fragmentado no qual o CC é o eixo central 
das relações privadas e o CDC é lei especial destinada e elaborada para conferir proteção mais forte ao vulnerável, de maneira a proporcionar a construção de soluções jurídicas mais justas e legítimas ao jurisdicionado.

Informação bibliográfica deste texto, conforme a NBR 6023:2018 da Associação Brasileira de Normas Técnicas (ABNT):

PIERONI, Aline Martinez. Princípios gerais e princípios contratuais: Código Civil x Código de Defesa do Consumidor. Revista Brasileira de Direito Civil - RBDCivil, Belo Horizonte, v. 28, p. 43-75, abr./jun. 2021.

Recebido em: 16.10.2019

1ㅇp parecer em: 31.07 .2020

2o parecer em: 21.09.2020 